\title{
Blood flukes (Digenea: Aporocotylidae) infecting body cavity of South American catfishes (Siluriformes: Pimelodidae): two new species from rivers in Bolivia, Guyana and Peru with a re-assessment of Plehniella Szidat, 1951
}

\author{
Raphael Orélis-Ribeiro and Stephen A. Bullard
}

Aquatic Parasitology Laboratory, School of Fisheries, Aquaculture and Aquatic Sciences, College of Agriculture, Auburn University, Auburn, Alabama, USA

\begin{abstract}
Plehniella Szidat, 1951 is emended based on new collections from South American long-whiskered catfishes. It is clearly differentiated from Sanguinicola Plehn, 1905 by lacking lateral tegumental body spines and by having 6 asymmetrical caeca. Plehniella sabajperezi sp. n. infects body cavity of Pimelodus albofasciatus (Mees) from the Demerara and Rupununi Rivers (Guyana) and Pimelodus blochii (Valenciennes) from Lake Tumi Chucua (Bolivia) and Napo River (Peru). It differs from Plehniella coelomicola Szidat, 1951 (type species) by having a thin-walled vas deferens that greatly exceeds the length of cirrus-sac and that joins the cirrus-sac at level of ovovitelline duct and ootype, an internal seminal vesicle that is absent or diminutive, and a cirrus-sac that is spheroid, nearly marginal, and envelops the laterally-directed distal portion of the male genitalia. Plehniella armbrusteri sp. $\mathrm{n}$. infects body cavity of P. blochii from Lake Tumi Chucua (Bolivia). It differs from P. coelomicola and P. sabajperezi by having a relatively ovoid body, a massive intestine comprising caeca that are deeply-lobed to diverticulate and terminate in the posterior half of the body, a testis that flanks the distal tips of the posteriorly-directed caeca, and a proximal portion of the vas deferens that loops ventral to the testis. Small adults (Plehniella sp.) collected from body cavity of Pimelodus grosskopfii (Steindachner) from Cienega de Jobo and Canal del Dique (Colombia) differ from congeners by having a posteriorly-constricted body region, an anterior sucker with concentric rows of minute spines, an elongate anterior oesophageal swelling, short and wide caeca, and a male genital pore that opens proportionally more anteriad. This study nearly doubles the number of aporocotylids documented from South America Rivers and comprises the first record of a fish blood fluke from P. blochii, P. albofasciatus and P. grosskopfii as well as from Bolivia, Colombia, Guyana or Peru.
\end{abstract}

Keywords: taxonomy, Plehniella albofasciatus, Plehniella armbrusteri, Plehniella coelomicola, Pimelodus

A dearth of information exists regarding the taxonomic diversity, hosts and geographic distributions of 'fish blood flukes' (Digenea: Aporocotylidae) in South American rivers. This significant portion of the Neotropical region arguably harbours the most diverse freshwater ichthyofauna on the Earth, estimated to exceed 4000 species (Reis 2013). However, only three of $136(2 \%)$ aporocotylid species assigned to two genera reportedly infect five South American freshwater fishes from four genera: Sanguinicola argentinensis Szidat, 1951 infects heart and vessels leading to the gills of the streaked prochilodid, Prochilodus platensis (Holmberg) = Prochilodus lineatus (Valenciennes) (Characiformes: Prochilodontidae); Plehniella coelomicola Szidat, 1951 infects the body cavity of the long-whiskered catfishes (Siluriformes: Pimelodidae) Iheringichthys labrosus (Lütken), Pimelodus albicans (Valenciennes) and Pimelodus clarias maculatus $($ Bloch $)=$ Pimelodus macu- latus (Lacépède); and Plehniella platyrhynchi (Guidelli, Isaac et Pavanelli, 2002) (originally as Sanguinicola platyrhynchi Guidelli, Isaac et Pavanelli, 2002) infects body cavity of porthole shovelnose catfish, Hemisorubim platyrhynchos (Valenciennes) (Pimelodidae) (Table 1).

Pimelodidae includes 109 accepted species assigned to approximately 30 genera (Lundberg et al. 2010, Eschmeyer and Fong 2015) that range primarily in South America but also north to the central Panamanian Isthmus and into Mexico (Nelson 2006). Among catfishes as hosts, Pimelodidae has the highest number of records for aporocotylid infections (Truong and Bullard 2013) (Table 1), and it seems likely that additional species of Aporocotylidae remain unnamed in pimelodids ranging in South America. Nearly all of the known blood flukes that infect freshwater fishes mature in blood but those infecting pimelodids mature in body cavity (Szidat 1951, Truong and Bullard

Address for correspondence: R. Orélis-Ribeiro, Aquatic Parasitology Laboratory, School of Fisheries, Aquaculture, and Aquatic Sciences, College of Agriculture, Auburn University, 203 Swingle Hall, Auburn, Alabama 36849, USA. Phone: +1 334 844 9278; Fax: +1 334 844 9208; E-mail: ror0002@tigermail.auburn.edu

ZooBank number for article: urn:1sid:zoobank.org:pub:552C2D9A-42FA-4B94-B83A-8BB34A5A3A56 
Table 1. Blood flukes (Digenea: Aporocotylidae) of catfishes (Siluriformes).

\begin{tabular}{|c|c|c|c|c|}
\hline Aporocotylidae & Host & Site & Locality & Reference \\
\hline $\begin{array}{l}\text { Nomasanguinicola canthoensis } \\
\text { Truong et Bullard, } 2013\end{array}$ & $\begin{array}{l}\text { Clarias macrocephalus (Günther) } \\
\text { (Clariidae) }\end{array}$ & branchial vessels & $\begin{array}{l}\text { Can Tho fish market, } \\
\text { Vietnam } \\
\text { (Mekong River) }\end{array}$ & Truong and Bullard (2013) \\
\hline Plehniella armbrusteri $\mathrm{sp} . \mathrm{n}$. & $\begin{array}{l}\text { Pimelodus blochii (Valenciennes) } \\
\text { (Pimelodidae) }\end{array}$ & body cavity & $\begin{array}{l}\text { Lake Tumi Chucua, } \\
\text { Bolivia }\end{array}$ & present study \\
\hline \multirow[t]{6}{*}{$\begin{array}{l}\text { Plehniella coelomicola } \\
\text { Szidat, } 1951\end{array}$} & $\begin{array}{l}\text { Iheringichthys labrosus (Lütken) } \\
\text { (Pimelodidae) }\end{array}$ & body cavity & $\begin{array}{l}\text { La Plata River, } \\
\text { Argentina }\end{array}$ & Szidat (1951) \\
\hline & $\begin{array}{l}\text { Pimelodus albicans (Valenciennes) } \\
\text { (Pimelodidae) }\end{array}$ & body cavity & $\begin{array}{l}\text { La Plata River, } \\
\text { Argentina }\end{array}$ & $\begin{array}{l}\text { Lunaschi (1985), } \\
\text { Avendaño de Mac Intosh and } \\
\text { Ostrowski de Núñez (1998) }\end{array}$ \\
\hline & $\begin{array}{l}\text { Pimelodus maculatus (Lacépède) } \\
\text { (Pimelodidae) (as P. clarias macula- } \\
\text { tus } \text { [Bloch]) }\end{array}$ & body cavity & $\begin{array}{l}\text { La Plata River, } \\
\text { Argentina }\end{array}$ & Lunaschi (1985) \\
\hline & $\begin{array}{l}\text { Pimelodus maculatus (Lacépède) } \\
\text { (Pimelodidae) }\end{array}$ & body cavity & $\begin{array}{l}\text { La Plata River, } \\
\text { Argentina }\end{array}$ & $\begin{array}{l}\text { Avendaño de Mac Intosh and } \\
\text { Ostrowski de Núñez (1998) }\end{array}$ \\
\hline & Pimelodus maculatus & body cavity & $\begin{array}{l}\text { Paraná River Basin, } \\
\text { Brazil }\end{array}$ & $\begin{array}{l}\text { Brasil-Sato and Pavanelli } \\
(2004) \text {, } \\
\text { Takemoto et al. (2009) }\end{array}$ \\
\hline & Pimelodus maculatus & body cavity & $\begin{array}{l}\text { São Francisco River } \\
\text { Basin, Brazil }\end{array}$ & $\begin{array}{l}\text { Brasil-Sato (2003), } \\
\text { Brasil-Sato and Pavanelli } \\
(2004)\end{array}$ \\
\hline $\begin{array}{l}\text { Plehniella dentata } \\
\text { Paperna, } 1964 \text { incertae sedis }\end{array}$ & $\begin{array}{l}\text { Clarias gariepinus (Burchell) } \\
\text { (Clariidae) (as C. lazera [Valenci- } \\
\text { ennes]) }\end{array}$ & $\begin{array}{l}\text { 'intestine' (probably } \\
\text { mesenteric vessels) }\end{array}$ & $\begin{array}{l}\text { Lake Tiberia and } \\
\text { Hule Nature Reserve, } \\
\text { Israel }\end{array}$ & Paperna (1964) \\
\hline $\begin{array}{l}\text { Plehniella platyrhynchi } \\
\text { (Guidelli, Isaac et Pavanelli, } \\
\text { 2002) comb. n. (originally as } \\
\text { Sanguinicola) }\end{array}$ & $\begin{array}{l}\text { Hemisorubim platyrhynchos } \\
\text { (Valenciennes, 1840) (Pimelodidae) }\end{array}$ & body cavity & Paraná River, Brazil & $\begin{array}{l}\text { Guidelli et al. (2002), } \\
\text { Truong and Bullard (2013) }\end{array}$ \\
\hline \multirow[t]{4}{*}{ Plehniella sabajperezi sp. $\mathrm{n}$. } & $\begin{array}{l}\text { Pimelodus albofasciatus (Mees) } \\
\text { (Pimelodidae) }\end{array}$ & body cavity & $\begin{array}{l}\text { Demerara River, } \\
\text { Guyana }\end{array}$ & present study \\
\hline & Pimelodus albofasciatus & body cavity & $\begin{array}{l}\text { Rupununi River, } \\
\text { Guyana }\end{array}$ & present study \\
\hline & $\begin{array}{l}\text { Pimelodus blochii (Valenciennes) } \\
\text { (Pimelodidae) }\end{array}$ & body cavity & $\begin{array}{l}\text { Lago Tumi Chucua, } \\
\text { Bolivia }\end{array}$ & present study \\
\hline & Pimelodus blochii & body cavity & Napo River, Peru & present study \\
\hline Plehniella sp. & $\begin{array}{l}\text { Pimelodus grosskopfii (Steindachner) } \\
\text { (Pimelodidae) }\end{array}$ & body cavity & $\begin{array}{l}\text { Cienega de Jobo and } \\
\text { Canal del Dique, } \\
\text { Colombia }\end{array}$ & present study \\
\hline \multirow[t]{2}{*}{$\begin{array}{l}\text { Sanguinicola chalmersi } \\
\text { Odhner, } 1924\end{array}$} & $\begin{array}{l}\text { Auchenoglanis occidentalis } \\
\text { (Valenciennes) (Claroteidae) }\end{array}$ & blood, heart & Sudan, Africa & $\begin{array}{l}\text { Woodland }(1923) \text {, } \\
\text { Odhner }(1924), \\
\text { Khalil }(1969,1971) \text {, } \\
\text { Paperna }(1996)\end{array}$ \\
\hline & $\begin{array}{l}\text { Synodontis schall } \\
\text { (Block and Schneider) (Mochoidae) }\end{array}$ & $\begin{array}{l}\text { mesenteric and branchial } \\
\text { blood vessels }\end{array}$ & $\begin{array}{l}\text { Cairo and Giza fish } \\
\text { markets, Egypt }\end{array}$ & $\begin{array}{l}\text { Woodland (1923), } \\
\text { Imam et al. (1984) }\end{array}$ \\
\hline \multirow{2}{*}{$\begin{array}{l}\text { Sanguinicola clarias } \\
\text { Imam, Marzouk, Hassan et It- } \\
\text { man, } 1984 \text { incertae sedis }\end{array}$} & $\begin{array}{l}\text { Clarias gariepinus (Burchell) } \\
\text { (Clariidae) (as C. lazera) }\end{array}$ & $\begin{array}{l}\text { 'mesenteric and other } \\
\text { blood vessels' }\end{array}$ & $\begin{array}{l}\text { Cairo and Giza fish } \\
\text { markets, Egypt }\end{array}$ & Imam et al. (1984) \\
\hline & & not specified & $\begin{array}{l}\text { Beni-Suef fish } \\
\text { market, Egypt }\end{array}$ & $\begin{array}{l}\text { Imam and El-Askalany } \\
(1990)\end{array}$ \\
\hline
\end{tabular}

2013). However, seemingly few workers search the body cavity of fishes for infections and perhaps this unusual site of infection explains why so few species of Plehniella Szidat, 1951 are known to date. The taxonomy of nominal aporocotylids infecting pimelodids also needs revision. As reflected in the taxonomic literature since the 1950's, Plehniella has largely been ignored and no taxonomic assessment of the genus based upon a study of specimens has been published since Lunaschi (1985).

Herein, we describe two new species of Plehniella and emend the diagnosis of the genus. We also provide several new host and geographic locality records for Plehniella (Table 1), including the first records of a fish blood fluke from Bolivia, Colombia, Guyana and Peru.

\section{MATERIALS AND METHODS}

Specimens of Pimelodus blochii (Valenciennes) were captured by seine and cast net from the Napo River $\left(3^{\circ} 29^{\prime} \mathrm{S} ; 73^{\circ} 5^{\prime} \mathrm{W}\right)$ (Peru) and killed by spinal severance at necropsy. Living flukes intended as whole-mounts were killed with heat from an ethanol-burner flame under slight coverslip pressure and transferred to a vial of $5 \%$ neutral buffered formalin (n.b.f.). Three species of pimelodid catfish from the Auburn University Natural History Museum Fish Collection (AUM) were examined for the presence of aporocotylid infections. The number, collection date, geographic locality and AUM catalogue numbers of examined fishes are as follows: for Pimelodus albofasciatus (Mees), three fish specimens collected 17-18 October 1998 from the Demerara River (555'59"N; 58 18'21"W), Atlantic Ocean Basin, Guyana, AUM 27947; five fish specimens collected 15 November 2007 from the Rupununi River $\left(3^{\circ} 55^{\prime} 04^{\prime \prime N}\right.$; 5906'01"W), Essequibo River Basin, Guyana, AUM 49616; for P. blochii, 14 specimens collected 5-10 November 1981 from Lake Tumi Chucua, tributary to the Beni River (1007'S; $\left.66^{\circ} 11^{\prime} \mathrm{W}\right)$, Madeira River Basin, Bolivia, AUM 23544; and for Pimelodus grosskopfii (Steindachner), nine specimens collected 7 September 1978 from Cienega de Jobo and 
Canal del Dique (10²0'59"N; 7458'00"W), Magdalena River Basin, Colombia, AUM 35398. These fish were formalin-fixed in the field (immersed and abdominally injected) and subsequently transferred to, and held in, 70\% EtOH. The body cavity of each fish was slit by a ventrolongitudinal incision by scalpel and rinsed with distilled water over a Petri dish such that the contents could then be examined for the presence of fish blood flukes with the aid of a stereo dissecting microscope. Discovered aporocotylid specimens then were transferred to and held in a vial of $5 \%$ n.b.f.

All resulting aporocotylid specimens intended as whole mounted specimens were removed from n.b.f., rinsed thoroughly with distilled water and cleaned with fine brushes to remove any debris, stained overnight in Van Cleave's hematoxylin with several additional drops of Ehrlich's hematoxylin, made basic at $70 \%$ ethanol with lithium carbonate and butylamine, dehydrated, cleared in clove oil, and permanently mounted on glass slides using Canada balsam. Illustrations of stained, whole-mounted specimens were made with the aid of a Leica DM-2500 equipped with differential interference contrast optical components and a drawing tube. Measurements were made using a calibrated ocular micrometre (as straight-lines along the course of the ducts) and are herein reported in micrometres $(\mu \mathrm{m})$ as a range followed by, in parentheses, the mean and number of measurements taken. Scientific names including taxonomic authorities and dates for fishes follow Eschmeyer (2015). Common names are taken from FishBase (Froese and Pauly 2015). Higher level fish classification and nomenclature follows Nelson (2006). Nomenclature for the Aporocotylidae follows Bullard et al. (2009). Brown (1956) was used to help construct the genus name and specific epithet. Stephen S. Curran (Gulf Coast Research Laboratory, Ocean Springs, Mississippi) collected the aporocotylid specimen from a Bloch's catfish that was captured in the Napo River (Peru) on 6 August 2001 .

\section{RESULTS}

\section{Plehniella Szidat, 1951 emended}

Figs. 1-16

Diagnosis. Body elongate or oblong in outline, with slight sinistral indentation at level of genitalia or not, approximately $1.5-4.0 \times$ longer than wide, dorsoventrally flattened, ventrally concave, anterior and posterior ends tapering equally or having a broadly rounded posterior end, lacking tegumental body spines, rod-like, or bristle-like structures in adult. Ventrolateral nerve cords indistinct; dorsolateral nerve cords present.

Mouth medioventral. Anterior sucker with concentric spine rows present in small adult specimens, demarcated from body by posterior constriction of tegument, an obvious proboscis with concentric spine rows. Pharynx diminutive, apparently muscular, with triradiate lumen, in anterior portion of oesophagus. Oesophagus medial, moderately sinuous, extending posteriad approximately $1 / 3-1 / 2$ of body length, including anterior and posterior oesophageal swellings enveloped by glands. Intestine having glandular wall; comprising 6 caeca; caeca asymmetrical, smooth or diverticulate.

Testis single, diffuse, having many laterally-directed lobes. Vasa efferentia extensive, having secondary ducts extending from lateral margins of testicular lobes and coa- lescing ventrally along midline and forming a single large vas deferens; vas deferens transverse, crossing midline, with proximal portion extending straight or looping ventral to testis. Cirrus-sac present.

Ovary single, medial or slightly dextral, post-testicular, occupying posterior $1 / 3$ of body, a loose aggregation of spheroid ova bound by a thin membrane, strongly diverticulate, having deep lobes with middle portion narrow and comprising dorsal and ventral cords spanning midline of body, hourglass- or butterfly-shaped in outline, dorsal to vas deferens. Vitellarium follicular, occupying space from mid-oesophagus to testis or middle of ovary. Oviduct emanating from posteromedial dorsal surface of ovary, expanding in proximal portion to form an oviducal seminal receptacle, connecting with distal portion of vitelline duct before joining with ootype. Ootype massive, post-caecal, post-gonadal. Laurer's canal absent.

Uterus a relatively abbreviated duct connecting ootype and metraterm, straight (lacking convolutions or coils), post-caecal, post-gonadal; uterine seminal receptacle not evident; uterine egg not observed. Metraterm present, sinistral. Male and female reproductive tracts sharing common atrium and pore; dorsal, post-gonadal, sinistral, submarginal. In body cavity of South American pimelodid catfishes.

Differential diagnosis. Ventrolateral tegumental body spines absent. Anterior sucker absent in large adult specimens; small adult specimens having spinous anterior sucker with concentric spine rows. Pharynx present. Oesophagus $1 / 3-1 / 2$ of body length, with anterior and posterior oesophageal swellings enveloped by oesophageal glands. Intestine comprising 6 asymmetrical, sac-like caeca. Testis single, diffuse, having many laterally-directed lobes. Vas deferens transverse, crossing midline, with proximal portion extending straight or comprising anterior loops ventral to testis. Cirrus-sac present. Ovary having deep-lobes. Ootype massive. Uterus a relatively abbreviated duct connecting ootype and metraterm, straight (lacking convolutions or coils). Common genital atrium and pore present.

Type species: Plehniella coelomicola Szidat, 1951.

Remarks. Szidat (1951) proposed Plehniella for P. coelomicola, specimens of which he excised from the body cavity of several formalin-fixed specimens of Iheringichthys labrosus (Lütken) originally collected from the filters of a water treatment plant in Buenos Aires. He also reported immature specimens of Plehniella sp. from the body cavity of similarly-sourced specimens of Pimelodus maculatus (Lacépède) (as $P$. clarias [Bloch]). He posited that these small adult specimens infecting $P$. maculatus could have represented a species distinct from $P$. coelomicola that simply was not adapted for infecting this host and, as a result, did not develop further.

Regarding the nomenclature of the type species, some publications have reported the specific epithet as "coelomica" (Avendaño de Mac Intosh and Ostrowski de Núñez 1998, Brasil-Sato 2003, Brasil-Sato and Pavanelli 2004, Takemoto et al. 2009) rather than "coelomicola" as per Szidat (1951). We suspect that after Yamaguti (1958) re-assigned P. coelomicola to Sanguinicola, it was considered 
necessary to have agreement in gender between the specific-group name and the generic name with which it is combined. However, articles 31.2.1 and 34.2.1 of the ICZN state that "if the species-group name is a noun," its ending does not need to agree in gender with the generic name with which it is combined. Hence, we accept only $P$. coelomicola and consider 'Plehniella coelomica' (op. cit.) an invalid nomenclatural act.

Szidat (1951) and Lunaschi (1985) diagnosed Plehniel$l a$, and the character states detailed in each diagnosis are worthy of comparison with those of the emended diagnosis herein. Szidat's (1951) original diagnosis was relatively non-restrictive but included the presence of 6 caeca, which is a key feature that differentiates the genus from all other aporocotylid genera. An additional feature that readily differentiates adult specimens of Plehniella from those of Sanguinicola and many other aporocotylid genera is the absence of lateral tegumental body spines. Szidat's (1951) diagnosis (translated from German) stated, "Aporocotylidae with wide oval, leaf-shaped body that dwells in body cavity of their hosts (so far freshwater fishes of South America). Inner organisation of gut apparatus and of reproductive glands resembles Sanguinicola Plehn, 1905; however, the cirrus-sac is transformed into a large half-circle shaped organ because of the strongly developed prostatic part. Uterus short, containing one egg. Always six gut diverticula."

Among the accepted genera of Aporocotylidae, Plehniella is probably most similar to 'Sanguinicola'; however, the intestine of Plehniella spp. is markedly distinct from that of Sanguinicola armata Plehn, 1905 (type species) in that it has 6 caeca (present study, Szidat 1951) rather than 4 (or 5) as in Sanguinicola (see Plehn 1905, Ejsmont 1926). Similarly, the genitalia typical of species in these genera are markedly distinct: in Plehniella the vas deferens is strongly sinuous and runs transverse to the midline of body, the terminal male genitalia includes a pronounced cirrus-sac, and the female genitalia include an ootype and metraterm that together form an arch at level of the cirrus-sac. In $S$. armata, the vas deferens extends approximately directly posteriad, the cirrus-sac is indeterminate but diminutive if present, and the uterus is truncated, comprising a short duct that extends anteriad from the ootype (Plehn 1905, Ejsmont 1926). We were unable to confirm an egg in any of our specimens, but it is noteworthy that Szidat's mention of "uterus containing one egg" is similar to that reported by Ejsmont (1926) for S. armata.

Further, Sanguinicola spp. seemingly have a lanceolate body with tegumental spines arranged in a single lateral column, testicular lobes perpendicular to the midline, and an ovary margin that has a deep median notch anteriorly and posteriorly (giving the ovary an outline resembling an hourglass or butterfly wings). Plehn's (1905) original descriptions of S. armata and Sanguinicola inermis Plehn, 1905 are depicted as having 4 or 5 caeca, respectively, but that latter configuration needs confirmation. We have not seen it in any specimen of any species of Sanguinicola (personal observations SAB) and no description of any species of Sanguinicola since Plehn (1905) has included a fifth caecum. Finally, although spine shape and distribution need confirmation for several species of Sanguinicola, we regard the genus as having a single column of lateral tegumental body spines (as exhibited by the type species of the genus), whereas large adult specimens of Plehniella spp. lack tegumental spines altogether.

Expanding on those features of Plehniella 34 years later, Lunaschi's (1985) diagnosis (translated from Spanish) stated, "Body leaf-shaped; cuticle smooth [lacking spines]. Mouth subterminal with tri-radiate lumen, internally marked by three structures or muscular processes; pharynx absent; oesophagus long; intestine comprising six short diverticula [caeca] that reach equatorial region of body. Common genital pore dorsal, subterminal and submedian. Cirrus-sac not defined. Testis diffuse, medial, in posterior part of middle third of body, between intestinal diverticula and ovary; prostatic region large. Ovary with a strong central constriction, forming two large symmetrical lobes, each lobe multilobed, oviduct large; ootype ample; uterus routing in parallel to prostatic duct, opening into a small genital atrium. Vitelline glands comprising very small follicles distributing from posterior part of oesophagus to ovary; common vitelline duct passing parallel to oviduct to which it is united in its entrance to ootype. Parasites of coelomic cavity of freshwater fishes."

We confirmed the presence of nearly all of these features in our specimens and concur that some reliably circumscribe Plehniella. However, in disagreement with Lunaschi (1985), we regard species of Plehniella as having a pharynx, an intestine that extends posteriad and that may or may not reach the midbody region, a prominent cirrus-sac, and an ovary with asymmetrical lobes (see emended diagnosis above).

Plehniella spp. differ from the chondrichthyan blood flukes by lacking robust, C-shaped lateral tegumental body spines and a Laurer's canal. Features associated with the anterior sucker, lateral tegumental spines and genitalia differentiate Plehniella from the freshwater fish blood flukes assigned to Acipensericola Bullard, Snyder, Jensen et Overstreet, 2008 and Nomasanguinicola Truong et Bullard, 2013. Acipensericola differs from Plehniella by having a bowl-shaped anterior sucker, robust peg-like lateral tegumental spines, a column of testes, and a Laurer's canal; among other diagnostic features (Bullard et al. 2008). Nomasanguinicola differs from Plehniella most notably by the presence of an anterior sucker with denticles directing posteroventrally, forming a column per each side of mouth (Truong and Bullard 2013).

We are baffled by Yamaguti's (1958) decision to synonymise Plehniella with Sanguinicola and by the acceptance of this decision by subsequent authorities working with this group (Smith 2002, Nolan and Cribb 2005), especially considering the aforementioned, well-documented morphological and ecological differences between species of these genera. Regarding the obvious problems with Yamaguti's (1958) diagnosis of Sanguinicola, as written it does not accommodate Plehniella as diagnosed and clearly-illustrated by Szidat (1951). In specific, several features listed by Yamaguti (1958) as diagnostic for Sanguinicola 
are, beyond all doubt, lacking in Plehniella: "body lanceolate," "with fine marginal striations or denticulations," "intestine X-shaped, occasionally divided into 5 branches," "testes in two rows in median field between ovary and intestine," "uterus very short, containing only one egg, opening beside or anterior to male pore," and "parasitic in circulatory system of freshwater fishes."

Szidat (1951) reported that the genital pores in P. coelomicola were separate, whereas Lunaschi (1985) interpreted them as opening at a common pore. However, Szidat (1951) misinterpreted the shape and position of the uterus, which likely ultimately led to a misinterpretation of the genital opening. Szidat (1951) illustrated the uterus as a short inverted J-shaped feature connecting with a structure he labelled as the female genital pore. However, in our specimens the uterus arcs sinistrad before connecting to a metraterm. Szidat (1951) also likely misinterpreted the metraterm as an excretory bladder because he stated, "Of the excretory system one can only see the stem of the slightly sinuous collecting vessel or bladder which opens posterior to the male genital opening;" clearly describing the feature labeled as 'Ex.' ('Exkretionsblase') in his figures 4 and 5.

Plehniella platyrhynchi, the other aporocotylid that has 6 caeca and infects the body cavity of a pimelodid catfish in South America (i.e. Hemisorubim platyrhynchos), which was provisionally reassigned to Plehniella from Sanguinicola by Truong and Bullard (2013), appears to have adjacent but separate genital pores, among other diagnostic features, and its taxonomic status will be treated in greater detail elsewhere.

\section{Plehniella sabajperezi sp. $\mathrm{n}$.}

Figs. 1-5

ZooBank number for species:

urn:1sid:zoobank.org:act:03FF9D2A-11E3-4E8D-BD8B-C9474EBB22B1

Diagnosis (based on light microscopy of 10 whole-mounted large adult specimens): Body of adult 651-1352 (918; 9) long, 210-445 (294; 9) wide or 2.6$3.5 \times(3.1 \times ; 9)$ longer than wide; anterior body end more tapered than posterior end, notched on sinistral side at level of terminal genitalia, posterior end broadly rounded (Figs. 1, 2). Ventrolateral or lateral tegumental body spines absent in large adult specimens. Ventral and dorsal sensory papillae not evident with light microscopy. Ventrolateral nerve cords indistinct, secondary branches indistinct, dorsolateral nerve cords difficult to trace for most of body length; commissure of dorsolateral nerve cord 104-202 $(150 ; 6)$ or $11-24 \%(17 \% ; 6)$ of body length from anterior body end, $78-118(96 ; 5)$ across width of worm or $18-56 \%$ $(29 \% ; 5)$ of maximum body width, $3-11(6 ; 4)$ in diameter, perpendicular to long axis of body, coursing dorsal to posterior end of oesophageal anterior swelling (Fig. 1).

Anterior sucker not evident as a clearly delineated sucker separate from anterior region of body in large adult specimens; rows of spines on anterior end of body not evident; terminal papillae on anterior margin not present; denticles not present (Figs. 1, 2). Mouth 2-4 $(3 ; 10)$ in diameter,
$1 \%(1 \% ; 10)$ of maximum body width, 7-14 $(10 ; 10)$ long or $1-2 \%(1 \% ; 10)$ of body length from anterior body end (Figs. 1,2); pharynx immediately posterior to mouth, ovoid in outline, minute, $6-10(8 ; 9)$ long, $6-8(7 ; 10)$ wide, $3-4$ (3; 10) thick (Fig. 2).

Oesophagus $289-452(351 ; 10)$ long or $32-44 \%$ (38\%; 9) of body length, typically ( 8 out 10 specimens) dilating to $7-11(9 ; 8)$ immediately posterior to pharynx, extending sinuously posteriad for $12-35(20 ; 8)$ or $4-9 \%(6 \% ; 8)$ of oesophagus total length before gradually narrowing to 3-8 $(5 ; 8)$ and extending $17-67(31 ; 10)$ or $4-18 \%(9 \% ; 10)$ of oesophagus total length before connecting with anterior oesophageal swelling; anterior oesophageal swelling $47-87(70 ; 10)$ long or $6-9 \%(8 \% ; 10)$ of oesophagus total length, $12-27(19 ; 10)$ wide or $5-8 \%(7 \% ; 9)$ of maximum body width, with wall 4-10 $(7 ; 10)$ thick, 46-88 $(62 ; 10)$ or $5-8 \%(7 \% ; 9)$ of body length from anterior body end, delineated posteriorly by marked recurving of oesophagus ventrally. Oesophagus narrowing to $7-12(9 ; 10)$ posterior to anterior oesophageal swelling and extending sinuously posteriad 168-269 $(197$; 10) before connecting with posterior oesophageal swelling (Fig. 1). Posterior oesophageal swelling with elongate anterior portion and bulb-like posterior portion; anterior portion delineated anteriorly from narrow region of oesophagus by sharp bend of oesophagus; posterior portion immediately anterior to caecal ramification, $27-51(36 ; 10)$ long or $9-12 \%(10 ; 10)$ of oesophagus length, $20-33(24 ; 10)$ wide or $0.9-1.7 \times(1.3 \times ; 10)$ maximum oesophagus width, with wall $4-7(5 ; 7)$ thick, $215-392(291 ; 10)$ or $29-33 \%(31 \% ; 9)$ of body length from anterior body end, oblong, oriented diagonally (not parallel with longitudinal body axis), connecting with intestine anteromedially (Figs. 1, 3). Anterior oesophageal gland $140-162(152 ; 10)$ long, 86-132 $(100 ; 10)$ wide or $4.3-7.9 \times(5.3 \times ; 10)$ width of anterior oesophageal swelling (Fig. 1); posterior oesophageal gland 107-247 (146; 10) long or $34-55 \%(41 \% ; 10)$ of oesophagus length, 37-62 $(46 ; 10)$ wide or $1.5-2.8 \times(2.0 \times ; 10)$ width of posterior oesophageal swelling, a loose aggregation of large glandlike cells bound by a thin and lightly-staining membrane (Figs. 1, 3).

Intestine $240-377(310 ; 10)$ or $23-37 \%(34 \%, 9)$ of body length from anterior body end, with 6 clearly-differentiated caeca in all specimens examined; caeca (clockwise in ventral view from oesophagus-intestine connection) 25-65 (39; 9), 30-63 (45; 9), 30-65 (51; 9), 50-81 (65; 9), 42-80 $(60 ; 9), 28-60(45 ; 9)$ long or approximately $4-7 \%$ of body length and $10-17 \%$ of oesophagus length, $15-24(20 ; 9)$, 18-40 (28; 9), 20-47 (35; 9), 25-61 (43; 9), 26-51 (40; $9)$, and $20-56(31 ; 9)$ wide or approximately $10-16 \%$ of maximum body width and 1.1-1.8× maximum oesophagus width, smooth (lacking diverticula), wall glandular (not illustrated), containing refractive content (not illustrated); caecal field 106-210 $(142 ; 9)$ long or $16-18 \%(16 \% ; 8)$ of body length and $26-50 \%(41 \% ; 9)$ of oesophagus length, $72-146(116 ; 10)$ wide or $31-53 \%(42 \%, 9)$ of maximum body width; post-caecal distance $320-563(439 ; 10)$ or $38-56 \%(48 \%$; 9$)$ of body length from anterior body end, 

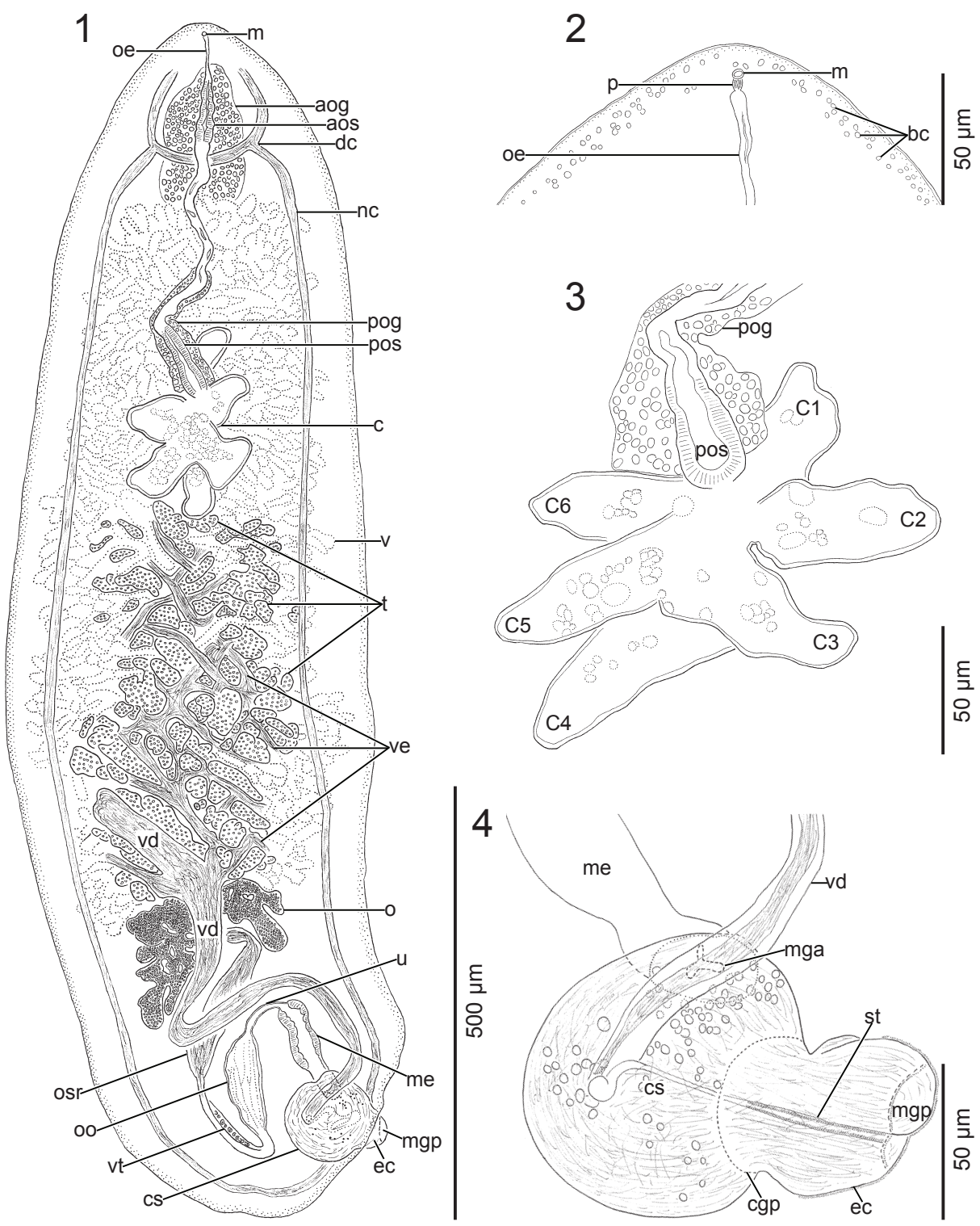

Figs. 1-4. Plehniella sabajperezi sp. n. (Digenea: Aporocotylidae) from body cavity of Pimelodus albofasciatus (Mees) (Siluriformes: Pimelodidae) from Demerara River, Guyana. Fig. 1. Holotype (USNM Coll. No. 1283479), ventral view. Fig. 2. Anterior end of holotype (USNM Coll. No. 1283479), ventral view. Fig. 3. High magnification view of caeca of paratype (IPCAS D-717), ventral view. Fig. 4. Higher magnification view of terminal genitalia of paratype (IPCAS D-717), ventral view. Abbreviations: aog - anterior oesophageal gland; aos - anterior oesophageal swelling; bc - basophilic cells; c - caecum; C1-C6 - sac-like caeca; cgp - common genital pore; cs - cirrus-sac; dc - anterior commissure of dorsolateral nerve cord; ec - everted cirrus; $\mathrm{m}$ - mouth; me - metraterm; mga - metraterm connection with common genital atrium; mgp - male genital pore; nc - nerve cord; o - ovary; oe - oesophagus; oo - ootype; osr - oviducal seminal receptacle; $p$ - pharynx; pog - posterior oesophageal gland; pos - posterior oesophageal swelling; st - sperm tube; $\mathrm{t}$ - testis; $\mathrm{u}$ - uterus; $\mathrm{v}$ - vitellarium; vd - vas deferens; ve - vasa efferentia; vt - vitelline duct (proximal extent not illustrated).

$324-771(499 ; 10)$ or $49-60 \%(53 \% ; 9)$ of body length from posterior body end (Figs. 1, 3).

Testis $154-456(246 ; 10)$ long or $20-35 \%(25 \%$; 9$)$ of body length, $111-248(165 ; 10)$ wide or $41-71 \%(54 \% ; 9)$ of body width or $1.1-1.9 \times(1.5 \times ; 10)$ longer than wide, containing dense field of vasa efferentia intertwining among densely-packed testicular cells; testicular cells circular, each measuring $1-5(3 ; 25)$ in diameter; post-testicular space $179-342(281 ; 10)$ long or $25-38 \%(30 \%$; 9$)$ of body length (Fig. 1). Vasa efferentia secondary ducts 2-25 (8; 29) wide, extending from lateral margins of testicular lobes (Fig. 1). Vas deferens a thin-walled duct, including a proximal portion ventral to testis and a post-testicular portion; proximal portion robust, $11-50(31 ; 10)$ wide, extending posteriad along midline; post-testicular portion 250-526 $(407 ; 10)$ long or $35-51 \%(44 \%$; 9$)$ of body length, $14-50$ $(35 ; 10)$ wide at level of posterior margin of testis, extending posteriad $30-107(72 ; 10)$ or $3-12 \%(8 \% ; 9)$ of body length before curving and extending 27-92 $(52 ; 9)$ toward dextral body margin, 9-45 $(28 ; 8)$ wide at level of ovary, curving ventromedially and crossing midline before narrowing to $5-22(14 ; 10)$ or $2-6.3 \%(4.6 \% ; 9)$ of maximum body width, continuing posteriad approximately in parallel with sinistral body margin before curving medially and connecting to ventral aspect of cirrus-sac (Figs. 1, 4, 5). 


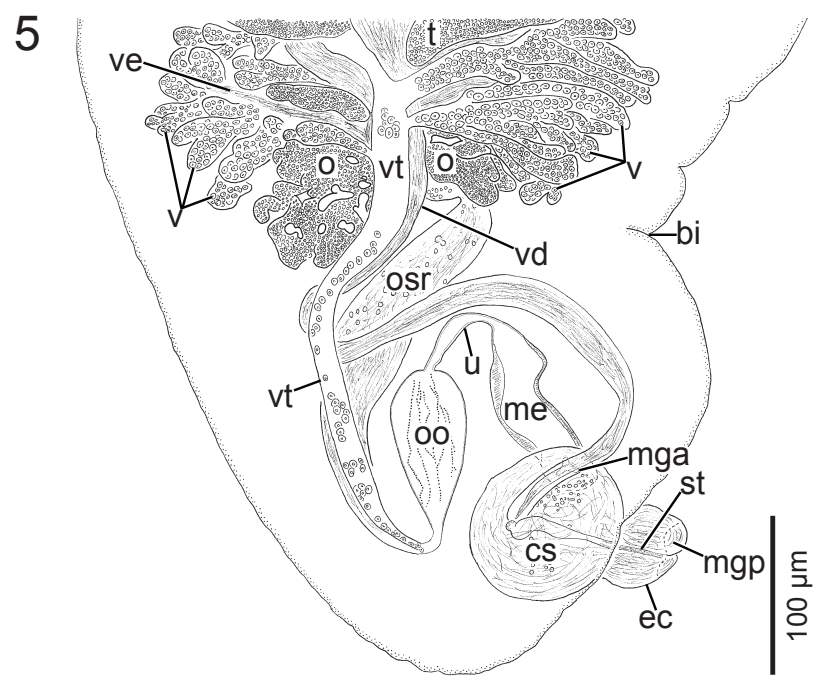

Fig. 5. Genitalia of Plehniella sabajperezi sp. n. (Digenea: Aporocotylidae) from body cavity of Pimelodus albofasciatus (Mees) (Siluriformes: Pimelodidae) from Demerara River, Guyana. Terminal genitalia of paratype (IPCAS D-717), ventral view. $A b$ breviations: bi - body indentation; cs - cirrus-sac; ec - everted cirrus; mga - metraterm connection with common genital atrium; mgp - male genital pore; me - metraterm; o - ovary; oo - ootype; osr - oviducal seminal receptacle, st - sperm tube; $\mathrm{t}$ - testis; $\mathrm{u}$ - uterus; ve - vasa efferentia; vd - vas deferens; v - vitellarium, vt - vitelline duct.

Cirrus-sac spheroid, nearly marginal, 46-112 (74; 9) long or $4-14 \%(8 \% ; 8)$ of body length, $47-104(79 ; 9)$ wide or $14-44 \%(26 \% ; 8)$ of maximum body width, $0.8-1.1 \times$ $(1 \times ; 9)$ longer that wide, having wall approximately $1(1$; 10) thick; internal seminal vesicle indistinct (Figs. 1, 4, 5). Inverted cirrus not observed. Everted cirrus and sperm duct laterally-directed, 36-61 $(49 ; 2)$ long or $41-76 \%(58 \% ; 2)$ of cirrus-sac length, base $42-53(48 ; 2)$ wide, expanding to 53 ( 1 of 2 specimens), narrowing in distal portion to $36-39(38 ; 2), 53$ (2) in maximum width or 0.5 (2) times cirrus-sac width, having minute external crenulations or ridges (not illustrated), with sperm tube coursing near ventral surface, and extending from common genital pore to beyond posterior body margin (Figs. 1, 4, 5).

Ovary having $3-7(5 ; 7)$ dextral and $2-4(3 ; 7)$ sinistral branches each $5-18(8 ; 45)$ wide, dextral and sinistral halves of ovary measuring 30-123 (78; 9) and 25-90 (52; $9)$ in maximum length or approximately $4-14 \%(8 \% ; 8)$ and $3-8 \%(5 \% ; 8)$ of body length, $70-207(145 ; 8)$ in maximum width or $33-60 \%(46 \% ; 7)$ of body width, $1-3 \times(2 \times$; 8) wider than long; post-ovarian space 165-233 (202; 9) long or $17-24 \%(21 \%$; 9) of body length (Figs. 1, 5). Oviduct curving sinistrally immediately posterior to ovary and lateral to vas deferens, $186-334(255 ; 10)$ long or $24-32 \%$ $(27 \% ; 9)$ of body length, including an abbreviated proximal duct, a dilated portion (= oviducal seminal receptacle), and a narrow distal portion; proximal duct emanating from posteroventral surface of ovary extending sinistrally 15-37 $(29 ; 10), 4-12(8 ; 10)$ in maximum width, curving posteromediad to connect with oviducal seminal receptacle; oviducal seminal receptacle filled with sperm and ova in all specimens, 97-246 $(167 ; 10)$ long or $51-74 \%(63 \% ; 10)$ of total oviduct length, $13-45(26 ; 10)$ wide or $3-10 \times(6 \times$; $10)$ longer than wide, occupying space between vas deferens and sinistral body margin, crossing vas deferens dorsally, post-ovarian; distal portion of oviduct $5-11(8 ; 10)$ or $21-54 \%(33 \%, 10)$ of oviducal seminal receptacle width, continuing posteriad approximately in parallel with dextral body margin before uniting with vitelline duct (Figs. 1, 5). Primary vitelline collecting duct indistinct in region anterior to ovary, passing ventral to ovary and extending ventrally along vas deferens before extending ventrally along oviducal seminal receptacle to unite with distal portion of oviduct immediately proximal to ootype. Ootype 42-107 (77; 9) long, 16-48 (33; 9) wide, 1.8-4.0× (2.5×; 9) longer than wide, connecting with vitelline duct and oviduct posteriorly, slightly dextral, orienting parallel to long axis of body; post-ootype distance $55-96(69 ; 9)$ or $6-8 \%(7 \% ; 8)$ of body length from posterior body end (Figs. 1, 5).

Uterus occupying space between ootype and vas deferens, extending $31-65(44 ; 8)$ or $4-6 \%(5 \% ; 7)$ of body length, $5-14(8 ; 8)$ in maximum width, curved or straight before connecting with metraterm (Figs. 1, 5). Metraterm $62-116(96 ; 9)$ long or $1.5-3.2 \times(2.3 \times ; 8)$ uterus length, $9-12 \%(10 \% ; 8)$ of body length, $12-38(25 ; 9)$ in maximum width, with wall 4-10 $(6 ; 8)$ thick, connecting with common genital atrium $15-46(27 ; 9)$ or $2-5 \%(3 \% ; 9)$ from posterior body end (Figs. 1, 4, 5). Common genital pore $20-40(29 ; 8)$ in diameter, opening $5-10(7 ; 3)$ or $1-2 \%$ $(1 \% ; 3)$ of body length from posterior body end (Figs. 1, 4, 5). Uterine eggs not observed.

Excretory system not observed.

Type host: Pimelodus albofasciatus (Mees) (Siluriformes: Pimelodidae).

Other hosts: Bloch's catfish, Pimelodus blochii (Valenciennes).

Type locality: Demerara River $\left(5^{\circ} 55^{\prime} 59^{\prime \prime N} ; 58^{\circ} 18^{\prime} 21^{\prime \prime}\right)$, Atlantic Ocean Drainage, Guyana.

Other localities: Specimens of P. albofasciatus captured from Rupununi River, Kwatamang Landing ( $3^{\circ} 55^{\prime} 04^{\prime \prime}$; 5906 $\left.01^{\prime \prime} \mathrm{W}\right)$, Essequibo River Drainage, Guyana; Bloch's catfish captured from Lake Tumi Chucua, tributary to Beni River, Dept. Beni, Prov. Vaca Diez $\left(10^{\circ} 07^{\prime} \mathrm{S}\right.$; $\left.66^{\circ} 11^{\prime} \mathrm{W}\right)$, Madeira River Basin, Bolivia; and Napo River $\left(03^{\circ} 29^{\prime} \mathrm{S}\right.$; $\left.73^{\circ} 05^{\prime} \mathrm{W}\right)$, a tributary of the Amazon River, Peru.

Site in host: Body cavity.

Prevalence and intensity of infection: Two of $3(67 \%)$ P. albofasciatus collected from Demerara River had $2-3$ (mean intensity $=2.5 \pm 0.5)$ specimens; one of $5(20 \%)$ P. albofasciatus collected from Rupununi River had 2 specimens; eight of 14 (57\%) Bloch's catfish collected from Lake Tumi Chucua had $1-13$ (mean intensity $=3.6 \pm 0.5$ ) specimens.

Specimens deposited: Holotype and two paratypes at the United States National Museum (USNM Coll. No. 1283479,1283480 and 1283481); one paratype at the Institute of Parasitology, Academy of Sciences of the Czech Republic, České Budějovice (IPCAS D-717).

Etymology: The specific epithet 'sabajperezi' honors Dr. Mark Henry Sabaj Pérez (Department of Ichthyology, The Academy of Natural Sciences, Philadelphia) for his contributions to our knowledge of fish biodiversity in South America. 
Remarks. Our specimens of $P$. sabajperezi resemble those of Szidat's (1951) originally described as P. coelomicola by each having an ovoid, extremely flattened body, a minute pharynx with a triradiate lumen, an oesophagus $<1 / 2$ body length, a thick-walled, glandular anterior and posterior oesophageal swelling, an intestine comprising 6 short caeca, a testis that is extensively branched, a cirrus-sac, an ovary in the posterior $1 / 3$ of body and having deep-lobed lateral lobes, and a prominent ootype that is slightly dextral. Both species also lack an anterior sucker in large adult specimens as well as lateral tegumental body spines or spination about the anterior body end and mouth.

These taxa can be most easily differentiated based upon the morphology of the terminal male genitalia. In $P$. coelomicola, and as described by Szidat (1951), the vas deferens crosses the ovary medioventrally and curves dextrad before extending laterad and crossing the midline where it becomes confluent with the massive, strongly musculoglandular internal seminal vesicle enveloped by the cirrussac. That is, the connection between the thin-walled vas deferens and musculo-glandular internal seminal vesicle in P. coelomicola is located between the level of the ovary and ootype. Szidat (1951) detailed the internal seminal vesicle as a "narrow duct surrounded by an immense layer of gland cells which contain a very fine glandular secretion." The internal seminal vesicle (and cirrus-sac) of $P$. coelomicola comprises over half of the length of the herein so-called 'afferent sperm duct' (comprising the vas deferens and internal seminal vesicle) and extends well anterior to the metraterm and ootype. As already stated, Szidat's (1951) figure 5 likely misinterprets the metraterm and female genital pore as an excretory duct/bladder extending posteriad along the midline, i.e. in figure 5 of Szidat (1951) the structure labeled "Ex." is the metraterm, not an excretory duct.

In contrast, the new species has a vas deferens that extends sinuously posteriad between the metraterm and sinistral dorsolateral nerve cord before connecting with the medial surface of the cirrus-sac in the posterior body extremity at level of the ovovitelline duct (Figs. 1, 5). We could not discern an internal seminal vesicle in our whole-mounted specimens; however, we suspect that one may be present, although likely diminutive if indeed present, as indicated by the presence of putatively secretory or glandular cells that are sporadically distributed at level of the cirrus-sac (Fig. 4). The cirrus-sac itself of the new species is spheroid, occupies the space posterior to the metraterm, and envelops the distal extent only of the terminal male genitalia. That is, the vas deferens of the new species is thin-walled for nearly its entire length, not enveloped by a sac and not associated with a thickened glandular or muscular wall. Features associated with the wall of the duct should not be confused with the amount of sperm in the duct, which could modulate the diameter of the vas deferens and internal seminal vesicle. In addition, in the new species the cirrus everts laterad (Figs. 1, 4, 5), not mediad (cf. Figs. 6, 9, 10 plus figure 5 in Szidat 1951), and the cirrus-sac itself is marginal in the sinistral side of the body.

In summary, the new species can be most easily differentiated from $P$. coelomicola by having a thin-walled vas deferens that greatly exceeds the length of cirrus-sac and that joins the cirrus-sac at level of ovovitelline duct and ootype, an internal seminal vesicle that is absent or diminutive, and a cirrus-sac that is spheroid, nearly marginal, and envelops the laterally-directed distal portion of the male genitalia only.

Plehniella armbrusteri sp. n.

Figs. 6-10

ZooBank number for species:

urn:1sid:zoobank.org:act:C75B9533-A380-42DC-A8EC-F6BF9870A55C

Diagnosis (based on light microscopy of 7 whole-mounted large adult specimens): Body of adult 1078-1438 (1270; 7) long, 514-716 $(602 ; 7)$ wide or $1.6-2.4 \times(2.1 \times$; 7) longer than wide, with ends tapering equally (Figs. 6, 7). Ventrolateral or lateral tegumental body spines absent in large adult specimens. Ventral and dorsal sensory papillae not evident with light microscopy. Ventrolateral nerve cords indistinct, secondary branches indistinct, dorsolateral nerve cords difficult to trace for most of length in all specimens; commissure of dorsolateral nerve cord 177-198 $(190 ; 4)$ or $14-16 \%(15 \% ; 4)$ of body length from anterior body end, 116-192 $(144 ; 3)$ across width of the worm or $19-30 \%(23 \% ; 3)$ of maximum body width, 5-10 $(6 ; 3)$ in diameter, perpendicular to long axis of body, coursing dorsal to posterior end of oesophageal anterior swelling.

Anterior sucker not evident as a clearly delineated sucker separate from anterior region of body in large adult specimens; rows of spines on anterior end of body not evident; terminal papillae on anterior margin not present; denticles not present (Figs. 6, 7). Mouth 8-13 $(11 ; 7)$ in diameter, $1-2 \%(2 \% ; 7)$ of maximum body width, $18-23(20 ; 7)$ long or $1-2 \%(2 \% ; 7)$ of body length from anterior body end (Figs. 6, 7); pharynx immediately posterior to mouth, ovoid in outline, minute, $13-15(14 ; 7)$ wide, 5-7 $(6 ; 7)$ thick (Fig. 7).

Oesophagus $456-560(512 ; 7)$ long or $36-44 \%$ (41\%; 7) of body length, typically (6 of 7 specimens) dilating to 14-23 $(18 ; 6)$ immediately posterior to pharynx, extending sinuously posteriad for $18-38(29 ; 6)$ or $3-12 \%(7 \% ; 6)$ of oesophagus total length, gradually narrowing to 4-11 $(9 ; 6)$ and dilating again to $12-24(19 ; 6)$, extending 20-52 (38; 6) or $4-10 \%(7 \% ; 6)$ of oesophagus total length, narrowing to $7-13(10,7)$ before connecting with anterior oesophageal swelling (Fig. 6); anterior oesophageal swelling 98-121 $(110 ; 7)$ long or $8-10 \%(9 \% ; 7)$ of oesophagus total length, $30-35(33 ; 7)$ wide or $5-7 \%(6 \% ; 7)$ of maximum body width, with wall 9-13 $(11 ; 7)$ thick, $80-99(90 ; 7)$ or $7-8 \%$ $(7 \% ; 7)$ of body length from anterior body end, delineated posteriorly by marked recurving of oesophagus ventrally. Oesophagus narrowing to $17-22(20 ; 7)$ posterior to anterior oesophageal swelling and extending sinuously posteriad 230-328 $(264 ; 7)$ before connecting posterior oesophageal swelling (Fig. 6). Posterior oesophageal swelling with elongate anterior portion and bulb-like posterior portion, anterior portion delineated anteriorly from narrow region of oesophagus by sharp bend of oesophagus; posterior portion immediately anterior to caecal ramification, 62-75 (69; 

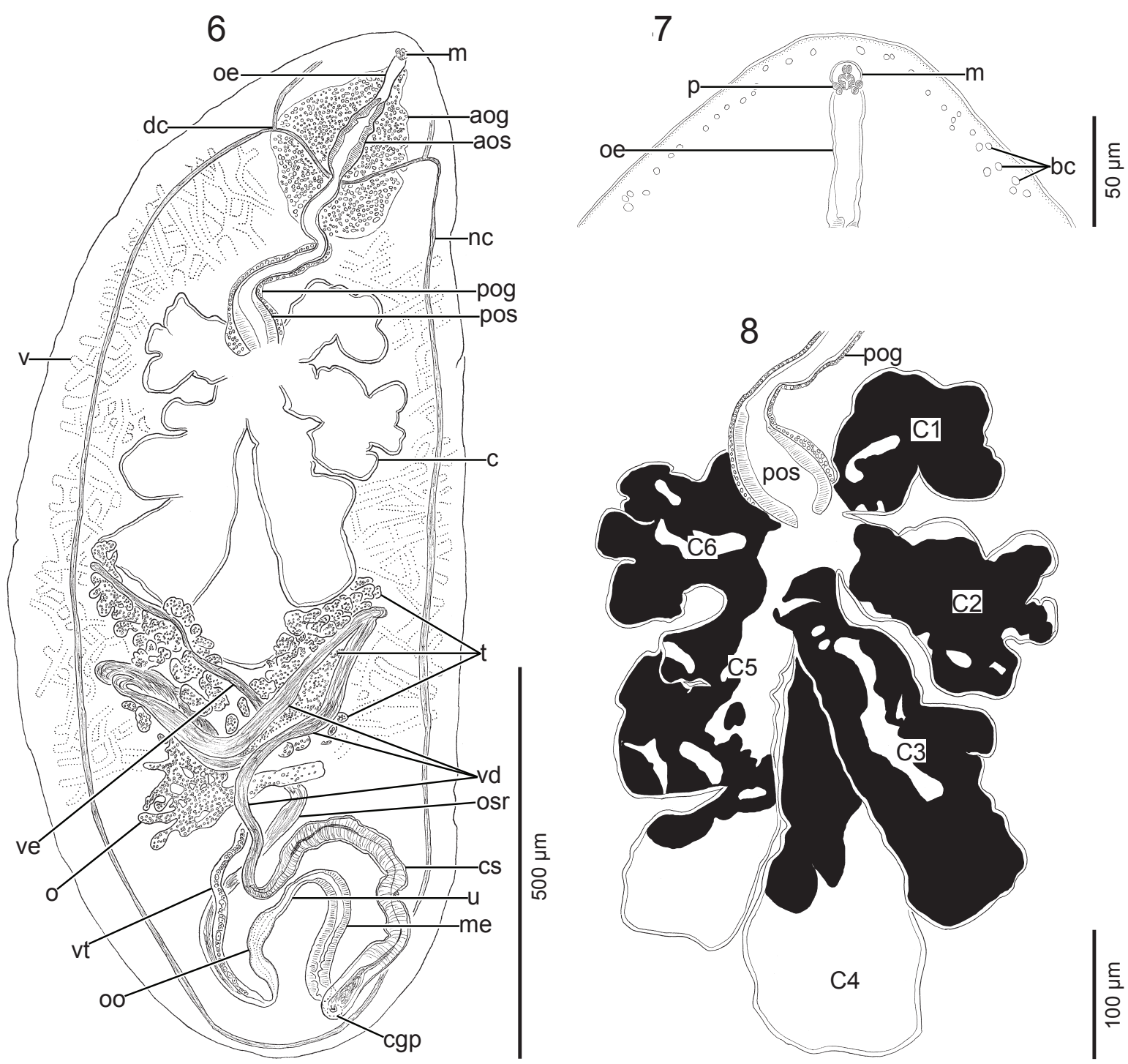

Figs. 6-8. Plehniella armbrusteri sp. n. from body cavity of Bloch's catfish, Pimelodus blochii (Valenciennes) (Siluriformes: Pimelodidae), from Lake Tumi Chucua, Bolivia. Fig. 6. Holotype (USNM Coll. No. 1283477), ventral view. Fig. 7. Anterior end of holotype (USNM Coll. No. 1283477), ventral view. Fig. 8. High magnification view of caeca of holotype (USNM Coll. No. 1283477), ventral view. Abbreviations: aog - anterior oesophageal gland; aos - anterior oesophageal swelling; bc - basophilic cells; c - caecum; C1-C6 - sac-like caeca; cs - cirrus-sac; cgp - common genital pore; dc - anterior commissure of dorsolateral nerve cord; $\mathrm{m}$ - mouth; me - metraterm; nc - nerve cord; o - ovary; oe - oesophagus; oo - ootype; osr - oviducal seminal receptacle; $p$ - pharynx; pog - posterior oesophageal gland; pos - posterior oesophageal swelling; $\mathrm{t}$ - testis; $\mathrm{u}$ - uterus; $\mathrm{v}$ - vitellarium; vd - vas deferens; ve - vasa efferentia; vt - vitelline duct.

7) long or $12-15 \%(14 \% ; 7)$ of oesophagus length, $38-56$ $(48 ; 7)$ wide or $1.1-1.7 \times(1.5 \times ; 7)$ maximum oesophagus width, with wall $6-10(9 ; 7)$ thick, ovoid in outline, oriented diagonally (not parallel with longitudinal body axis), connecting with intestine anteromedially (Figs. 6, 8). Anterior oesophageal gland 167-257 (209; 7) long, 143-235 $(179 ; 7)$ wide or $4.8-6.7 \times(5.5 \times ; 7)$ width of anterior oesophageal swelling; posterior oesophageal gland 225-345 $(267 ; 7)$ long or $42-62 \%(52 \% ; 7)$ of oesophagus length, $61-95(74 ; 7)$ wide or $1.3-1.9 \times(1.5 \times ; 7)$ width of posterior oesophageal swelling, a loose aggregation of large glandlike cells bound by a thin and lightly-staining membrane.

Intestine $394-505(455 ; 5)$ or $32-38 \%(35 \%, 5)$ of body length from anterior body end, with 6 clearly-differentiated caeca in all specimens examined, caeca (clockwise in ven- tral view from oesophagus-intestine connection) 105-130 (114; 6), 145-240 (191; 4), 205-270 (245; 4), 225-393 (302; 4), 160-363 (252; 4), and 135-235 (171; 5) long or approximately $15-19 \%$ of body length and $33-48 \%$ of oesophagus length, 57-130 (92; 6), 92-152 (121; 4), 65-148 (103; 4), 122-287 (166; 4), 95-204 (148; 4), and 54-160 $(99 ; 5)$ wide or approximately $16-25 \%$ of maximum body width and 5.7-12.6× maximum oesophagus width, deeplobed to diverticulate, wall glandular (not illustrated), containing refractive content; caecal field $305-541(444 ; 5)$ or $28-38 \%(34 \% ; 5)$ of body length and $67-102 \%(87 \% ; 5)$ of oesophagus length, $243-425(360 ; 4)$ wide or $37-70 \%$ $(60 \%, 4)$ of maximum body width; post-caecal distance $660-930(812 ; 5)$ or $61-65 \%(62 \% ; 5)$ of body length from 


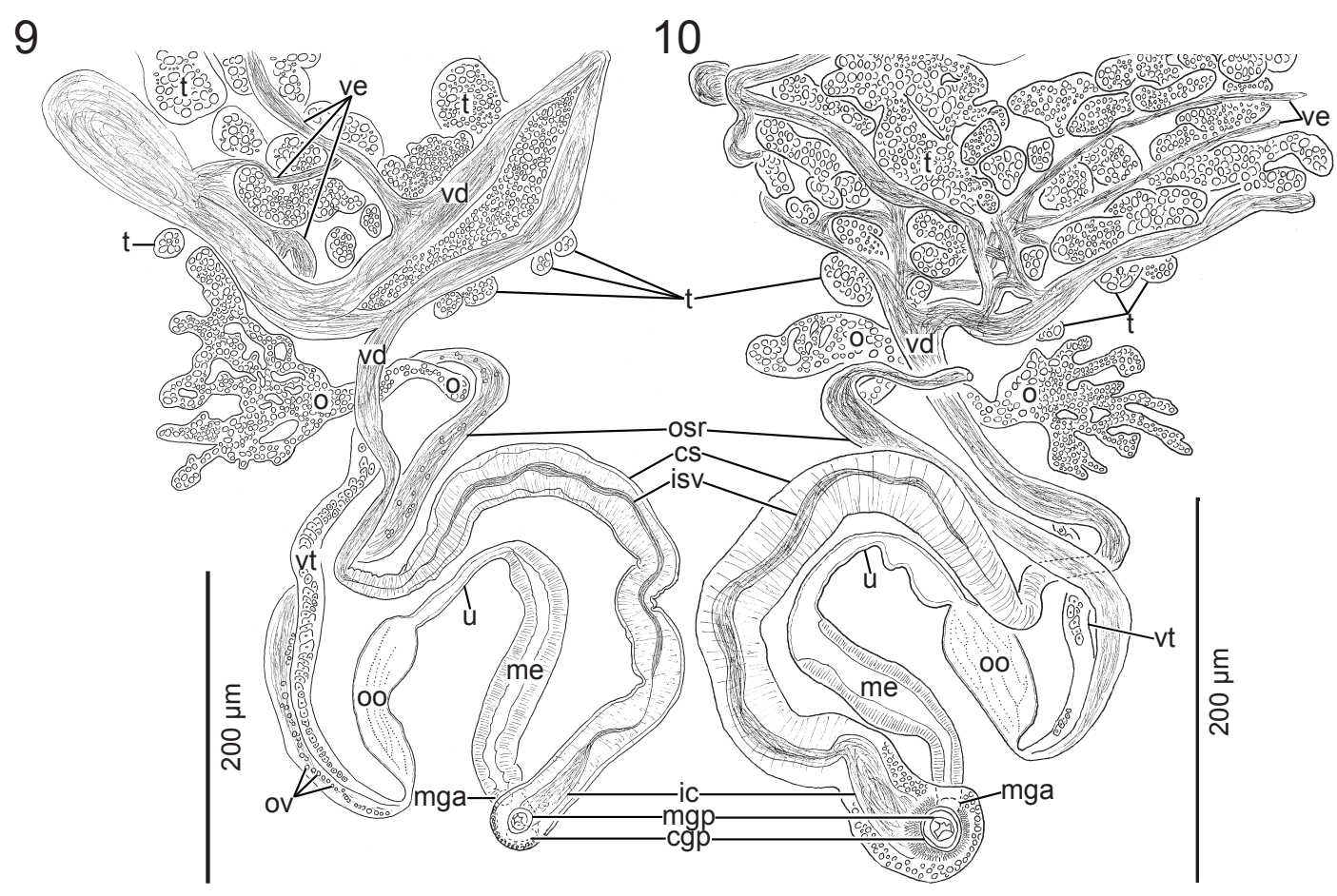

Figs. 9-10. Genitalia of Plehniella armbrusteri sp. n. from body cavity of Bloch's catfish, Pimelodus blochii (Valenciennes) (Siluriformes: Pimelodidae), from Lake Tumi Chucua, Bolivia. Fig. 9. Terminal genitalia of holotype (USNM Coll. No. 1283477), ventral view. Fig. 10. Terminal genitalia of paratype (IPCAS D-716), dorsal view. Abbreviations: cgp - common genital pore; cs - cirrus-sac; ic - inverted cirrus; isv - internal seminal vesicle; me - metraterm; mga - metraterm connection with common genital atrium; mgp - male genital pore; o - ovary; oo - ootype; osr - oviducal seminal receptacle; ov - ova; $t$ - testis; $u$ - uterus; vd - vas deferens; ve - vasa efferentia; vt - vitelline duct.

anterior body end, 395-521 $(460 ; 6)$ or $34-39 \%(37 \% ; 6)$ of body length from posterior body end (Figs. 6, 8).

Testis $198-305(249 ; 6)$ long or $15-25 \%(20 \% ; 6)$ of body length, $325-445(388 ; 6)$ wide or $56-75 \%(66 \% ; 4)$ of body width or $0.5-0.8 \times(0.6 \times ; 5)$ longer than wide, containing dense field of vasa efferentia intertwining among densely-packed testicular cells; testicular cells circular, each measuring $3-5(4 ; 7)$ in diameter; anteriorly flanking distal tips of 3 posteriorly-directed caeca; post-testicular space $290-446(361 ; 6)$ long or $26-39 \%(29 \%$; 6) of body length (Fig. 6). Vasa efferentia secondary ducts 2-30 (9; 16) wide extending from lateral margins of testicular lobes (Fig. 6). Vas deferens a thin-walled duct, including a proximal portion ventral to testis and a post-testicular portion; proximal portion robust, 16-23 $(19 ; 4)$ wide looping anteriorly before posterior end of testis. Post-testicular portion 193-245 $(215 ; 6)$ long, 16-20 (18; 3) wide at level of posterior margin of testis, extending posteriad 33-111 (75; $6)$ or $3-9 \%(6 \% ; 6)$ of body length before curving and extending 47-170 $(99 ; 6)$ toward dextral body margin, 16-29 $(22 ; 6)$ wide at level of ovary, curving ventromedially and extending $19-51(41 ; 6)$, narrowing to $10-18(14 ; 7)$ or $2-3 \%(2 ; 7)$ of maximum body width before connect with cirrus-sac and internal seminal vesicle, ventral to ovary, containing sperm in all specimens (Figs. 6, 9, 10).

Cirrus-sac C-shaped in outline, appendix-like, 403-522 $(481 ; 7)$ long or $32-43 \%(38 \% ; 7)$ of body length, $32-48$ $(40.1 ; 7)$ in maximum width or $5-9 \%(7 \% ; 7)$ of body width, 9.6-15.4× $(12.2 \times ; 7)$ longer that wide, with wall
3-4 $(3 ; 7)$ thick, wall glandular (Figs. 6, 9, 10); internal seminal vesicle occupying breadth and length of cirrus-sac to varying degrees depending on amount of sperm present in duct, 330-446 $(393 ; 7)$ long, 5-25 $(12 ; 7)$ wide or $17-84 \times(41 \times ; 7)$ longer that wide, extending toward sinistral margin before continuing posteriad approximately in parallel with sinistral body margin (Figs. 6, 9, 10); inverted cirrus $72-100(88 ; 7)$ long or $14-22 \%(18 \% ; 7)$ of cirrus-sac length; opening $24-29(26 ; 7)$ or $2-3 \%(2 \% ; 7)$ of body length from posterior body end, opening 65-145 $(102 ; 7)$ or $10-28 \%(17 \% ; 7)$ of maximum body width from sinistral body margin, opening $80-170(120 ; 7)$ or $15-24 \%(20 \% ; 7)$ of maximum body width from dextral body margin; slightly posteriad to metraterm connection with common genital atrium, slightly anteriad or coinciding with common genital pore opening (Figs. 6, 9, 10).

Ovary having $3-6(5 ; 5)$ dextral and $2-3(3 ; 2)$ sinistral branches each $3-18(8 ; 23)$ wide, dextral and sinistral halves of ovary measuring $85-133(101 ; 6)$ and $158-182$ $(170 ; 2)$ in maximum length or approximately $7-12 \%(8 \%$; $6)$ and $2-3 \%(3 \% ; 2)$ of body length, sinistral half of ovary difficult to trace in most of the specimens examined ( 5 of 7 specimens), 185 in maximum width or $28 \%$ of body width, $1.7 \times$ wider than long; post-ovarian space 192-285 (253; 6) long or $18-22 \%(20 \% ; 6)$ of body length (Figs. 6, 9, 10). Oviduct curving sinistrally immediately posterior to ovary and lateral to vas deferens, 368-483 (422; 7) long or $29-39 \%(33 \% ; 7)$ of body length, including an abbreviated proximal duct, a dilated portion (= oviducal seminal recep- 
tacle), and a narrow distal portion; proximal duct emanating from posteroventral surface of ovary extending sinistrally $37-98(67 ; 7), 9-13(10 ; 6)$ in maximum width, curving posteromediad to connect with oviducal seminal receptacle; oviducal seminal receptacle filled with sperm and ova in all specimens, $149-340(239 ; 7)$ long or $35-73 \%(54 \%$; $6)$ of total oviduct length, $25-45(31 ; 7)$ wide or $2.8-5.0 \times$ $(4.1 \times ; 7)$ longer than wide, occupying space between vas deferens and sinistral body margin, crossing vas deferens dorsally, post-ovarian; distal portion of oviduct 8-12 (10; $7)$ or $27-44 \%(32 \%, 7)$ of oviducal seminal vesicle width, continuing posteriad approximately in parallel with dextral body margin before uniting with vitelline duct (Figs. 6, 9, 10). Primary vitelline collecting duct indistinct in region anterior to ovary, passing ventral to ovary and extending ventrally along vas deferens before extending ventrally along oviducal seminal receptacle to unite with distal portion of oviduct immediately proximal to ootype. Ootype 75-109 (92; 7) long, 32-52 (44; 6) wide, 1.7-2.5× (2.1×; 7) longer than wide, connecting with vitelline duct and oviduct posteriorly, slightly dextral, orienting parallel to long axis of body; post-ootype distance $62-106(74 ; 7)$ or $5-8 \%$ $(6 \% ; 7)$ of body length from posterior body end (Figs. 6 , $9,10)$.

Uterus occupying space between ootype and cirrus; extending $62-90(75 ; 6)$ or $5-7 \%(6 \% ; 6)$ of body length, $11-14(13 ; 6)$ in maximum width, orienting diagonally anterosinistrad before connecting with metraterm (Figs. 6, 9, 10). Metraterm 156-256 (206; 6) long or 2-4× $(2.9 \times$; 4) longer than uterus, $12-20 \%(16 \% ; 6)$ of body length, $21-42(30 ; 6)$ in maximum width, with wall $5-10(6 ; 6)$ thick; connecting with common genital atrium 40-51 (44; 7 ) or $3-4 \%(4 \% ; 7)$ from posterior body end (Figs. 6, 9, $10)$. Common genital pore $16-20(18 ; 7)$ in diameter, opening $19-26(22 ; 7)$ or $2 \%(2 \% ; 7)$ of body length from posterior body end (Figs. 6, 9, 10). Uterine eggs not observed.

Excretory system not observed.

Type and only known host: Bloch's catfish, Pimelodus blochii (Valenciennes) (Siluriformes: Pimelodidae).

Type locality: Lake Tumi Chucua, tributary to Beni River, 26 km, Dept. Beni, Prov. Vaca Diez (1007'S; 66²11'W), Madeira River Basin, Bolivia.

Site in host: Body cavity.

Prevalence and intensity of infection: Two of 14 (14\%) Bloch's catfish had 1-8 specimens (mean intensity $=4.5 \pm 0.5)$.

S pecimens deposited: Holotype and one paratype at the United States National Museum (USNM Coll. No. 1283477 and 1283478); one paratype at the Institute of Parasitology, Academy of Sciences of the Czech Republic, České Budějovice (IPCAS D-716).

E ty mology: The specific name armbrusteri honors Dr. Jonathan W. Armbruster (Department of Biological Sciences, Auburn University Museum of Natural History) for his important contributions to the taxonomy of Neotropical catfishes.

Remarks. Plehniella armbrusteri is most easily distinguished from its congeners by the combination of having a relatively ovoid body 1.6-2.4 times longer than wide, a massive intestine (1/3 and $2 / 3$ of body length and width, respectively) comprising caeca that are deeply-lobed to diverticulate and that terminate in the posterior half of the body, a testis that flanks the distal tips of the posteriorly-directed caeca, and a proximal portion of the vas deferens that loops anteriad and ventral to the testis. As indicated previously, $P$. coelomicola has a smooth, non-diverticulate intestine that is proportionally smaller $(1 / 20$ and $1 / 7$ of body length and width, respectively) and terminates in the anterior half of the body. This species differs from $P$. armbrusteri also in that the testis does not extend anteriad to flank the posterior caeca, and the vas deferens does not loop ventral to the testis. Also as indicated previously, $P$. sabajperezi differs from $P$. armbrusteri by the combination of having a relatively elongate body that is $2.6-3.5 \times$ longer than wide and a posterior body end that is markedly more rounded than the anterior end, a relatively short intestine that terminates in the anterior body end and lacks diverticula, an anterior portion of the testicular field that surrounds only the most posterior caecum, an anterior portion of vas deferens that extends straight towards the end of testicular field without looping, an indistinct seminal vesicle, and a spheroid cirrus-sac.

\section{Plehniella sp.}

Figs. 11-16

Diagnosis (based on light microscopy of 10 whole-mounted small adult specimens): Body of small adults 365-500 (426; 10) long, 104-150 (135; 7) wide or $2.7-3.6 \times(3.2 \times ; 10)$ longer than wide, markedly recessed $42-87(64 ; 10)$ or $10-19 \%(15 \% ; 10)$ of body length from posterior end of body, ends tapering equally (Fig. 11). Ventrolateral or lateral tegumental body spines absent in small adult specimens. Ventral and dorsal sensory papillae not evident with light microscopy. Ventrolateral nerve cords indistinct, secondary branches indistinct, dorsolateral nerve cords difficult to trace for most of body length; commissure of dorsolateral nerve cord difficult to trace for most specimens.

Anterior sucker base $35-42(39 ; 10)$ width along constriction of tegument or $26-36 \%(29 \% ; 10)$ of body width, $21-26(23 ; 10)$ long or $1.5-1.9 \times(1.7 \times ; 10)$ wider than long; about 3 concentric rows of $<1$ long spines associated with anterior end, spines barely discernible with light microscope; terminal papillae on anterior margin not present; denticles not evident (Figs. 11, 12, 13). Mouth 3 (10) in diameter, $2-3 \%(2 \% ; 10)$ of maximum body width, 4-15 (9; $10)$ or $1-3 \%(2 \% ; 10)$ of body length from anterior body end (Figs. 11, 12, 13); pharynx immediately posterior to mouth, ovoid in outline, minute, 5-8 (6; 9), 4-7 (6; 10) wide, $2-3(3 ; 10)$ thick (Figs. 11, 12, 13).

Oesophagus $167-228(197 ; 10)$ long or $41-53 \%(46 \%$; 10) of body length, beginning as a narrow tube 2-6 (3; $10)$, extending slightly straight $23-39(30 ; 10)$ or $12-18 \%$ $(15 \% ; 10)$ of oesophagus total length before connecting with anterior oesophageal swelling (Fig. 11); anterior oesophageal swelling $29-39(34 ; 10)$ long or $14-20 \%$ $(17 \% ; 10)$ of oesophagus total length, $9-12(10 ; 10)$ wide or $7-10 \%(8 \% ; 10)$ of maximum body width, with wall $4-5(4 ; 10)$ thick, 33-47 $(41 ; 10)$ or $9-12 \%(10 \% ; 10)$ of 

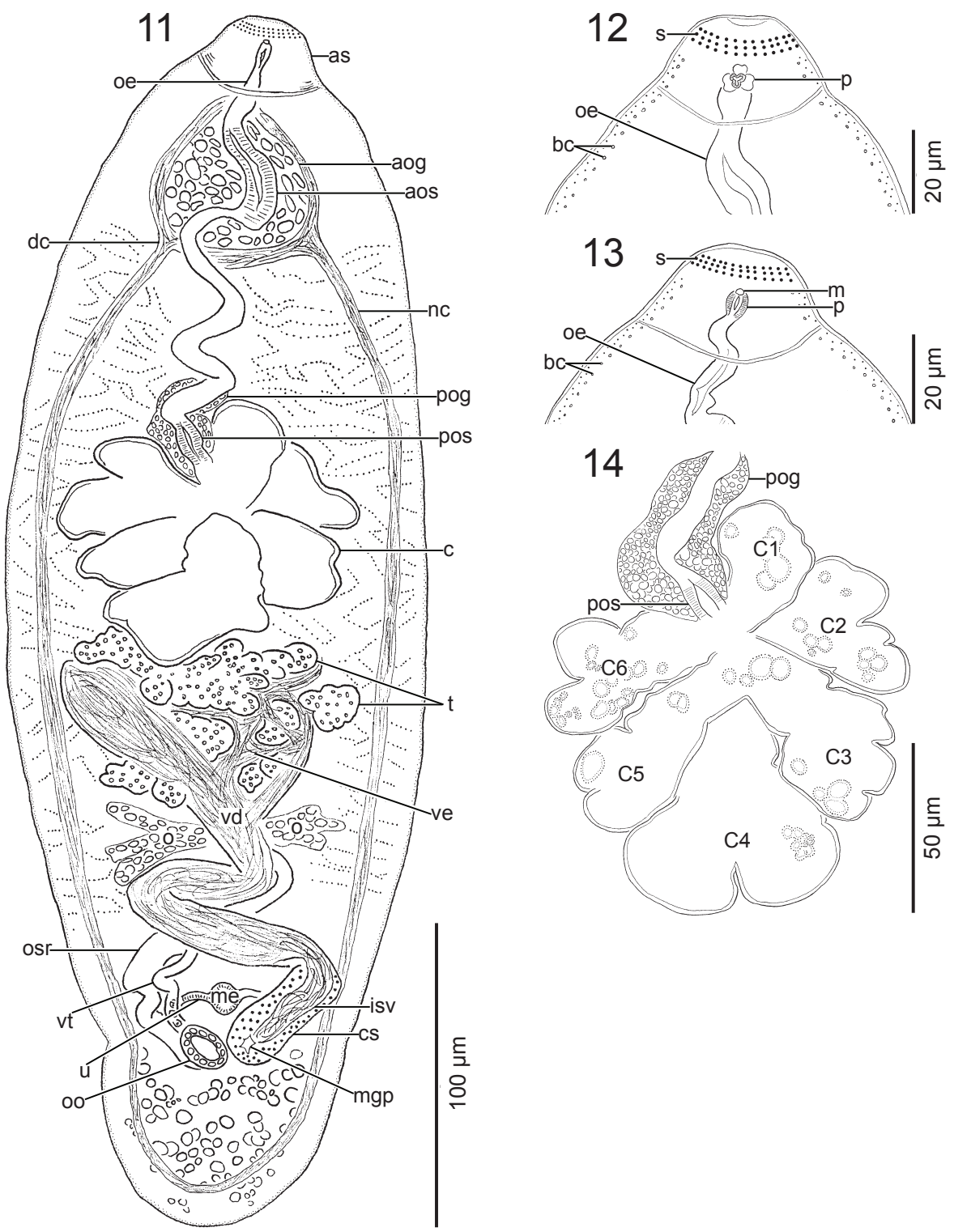

Figs. 11-14. Plehniella sp. from body cavity of Pimelodus grosskopfii (Steindachner) (Siluriformes: Pimelodidae) from Cienega de Jobo and Canal del Dique, Colombia. Fig. 11. Voucher (USNM Coll. No. 1283482), ventral view. Fig. 12. Anterior end of voucher (IPCAS D-718), ventral view. Fig. 13. Anterior end of voucher (USNM Coll. No. 1283482), ventral view. Fig. 14. High magnification view of caeca of voucher (IPCAS D-718), ventral view. Abbreviations: aog - anterior oesophageal gland; aos - anterior oesophageal swelling; as - anterior sucker; bc - basophilic cells; c - caecum; C1-C6 - sac-like caeca; cs - cirrus-sac; dc - anterior commissure of dorsolateral nerve cord; isv - internal seminal vesicle; me - metraterm; mgp - male genital pore; nc - nerve cord; o - ovary; oe - oesophagus; oo - ootype; osr - oviducal seminal receptacle; $p$ - pharynx; pog - posterior oesophageal gland; pos - posterior oesophageal swelling; $\mathrm{s}$ - row of spines; $\mathrm{t}$ - testis; $\mathrm{u}$ - uterus; ve - vasa efferentia; vd - vas deferens; vt - vitelline duct.

body length from anterior body end, delineated posteriorly by marked recurving of oesophagus ventrally. Oesophagus narrowing to $3-6(4.6 ; 10)$ posterior to anterior oesophageal swelling and extending sinuously posteriad $91.0-131.0$ (115.3; 10) before connecting with posterior oesophageal swelling. Posterior oesophageal swelling with elongate anterior portion and a bulb-like posterior portion, anterior portion delineated anteriorly from narrow region of oesophagus by sharp bend of oesophagus; posterior portion immediately anterior to caecal ramification, $3-26(18 ; 10)$ long or $3-5 \%(4 \% ; 10)$ of oesophagus length, $8-12(10$; 10) wide or $0.7-1.2 \times(1.0 \times ; 10)$ maximum oesophagus width, with wall $1-2(2 ; 10)$ thick, ovoid in outline, oriented diagonally (not parallel with longitudinal body axis), connecting with intestine anteromedially (Figs. 11, 14). Anterior oesophageal gland 45-53 (48; 3) long, 36-67 (55; 9) wide or $3.6-6.7 \times(5.3 \times$; 9$)$ width of anterior oesophageal swelling; posterior oesophageal gland 65-109 $(90 ; 10)$ long or $37-55 \%(46 \% ; 10)$ of oesophagus length, $18-32$ $(24 ; 10)$ wide or $1.6-4.0 \times(2.4 \times ; 10)$ width of posterior oesophageal swelling, a loose aggregation of large gland-like cells bound by a thin and lightly-staining membrane as in P. sabajperezi and P. armbrusteri.

Intestine $149-201(174 ; 9)$ or $38-47 \%(41 \%, 4)$ of body length from anterior body end; with 6 clearly-differentiated caeca in all specimens examined, caeca (clockwise in ventral view from oesophagus-intestine connection) 32-41 (38; 10), 36-56 (45; 10), 40-62 (48; 10), 35-63 (49; 10), 


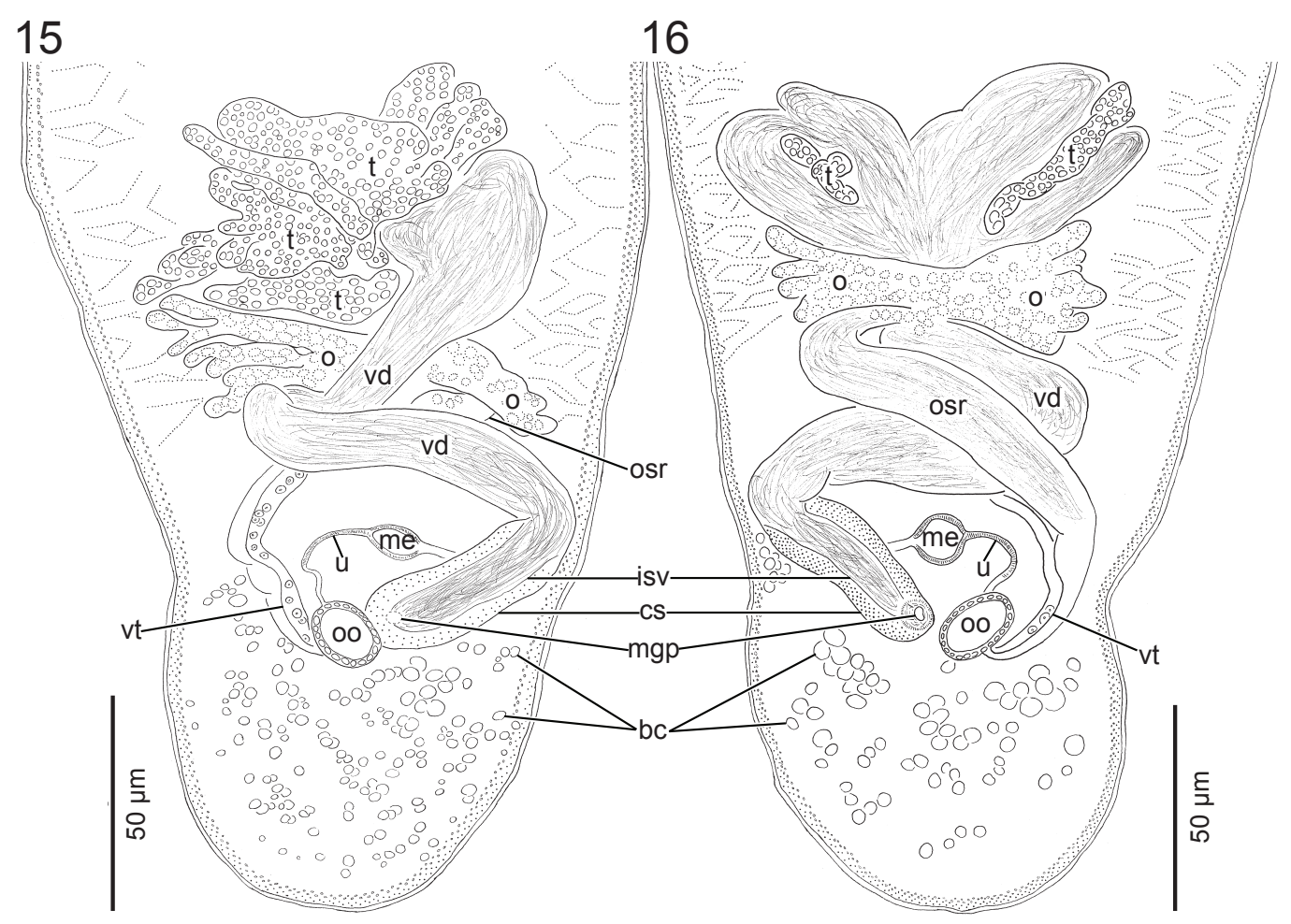

Figs. 15, 16. Genitalia of Plehniella sp. from body cavity of Pimelodus grosskopfii (Steindachner) (Siluriformes: Pimelodidae) from Cienega de Jobo and Canal del Dique, Colombia. Fig. 15. Terminal genitalia of voucher (IPCAS D-718), ventral view. Fig. 16. Terminal genitalia voucher (USNM Coll. No. 1283483), dorsal view. Abbreviations: bc - basophilic cells; cs - cirrus-sac; isv - internal seminal vesicle; me - metraterm; mgp - male genital pore; o - ovary; oo - ootype; osr - oviducal seminal receptacle; $\mathrm{t}$ - testis; $\mathrm{u}$ - uterus; vd - vas deferens; vt - vitelline duct.

$38-63(48 ; 10)$, and $33-56(44 ; 10)$ long or approximately $9-12 \%$ of body length and $16-26 \%$ of oesophagus length, 25-33 (30;10), 24-45 (37; 10), 24-47 (36; 10), 23-61 (42; 10), 20-43 $(30 ; 10)$, and $12-35(28 ; 10)$ wide or approximately $21-29 \%(25 \% ; 10)$ of maximum body width and $6.0-10.8 \times(8.3 \times ; 10)$ maximum oesophagus width, extending directly out from caecal ramification, deeplobed to diverticulate, some caeca branching near extremity, wall glandular (not illustrated), containing refractive content (not illustrated); caecal field $69-120(94 ; 10)$ or $19-26 \%(22 \% ; 10)$ of body length and $35-62 \%(48 \% ; 10)$ of oesophagus length, $81-111(101 ; 10)$ wide or $71-82 \%$ $(75 \%, 10)$ of maximum body width; post-caecal distance $201-283(234 ; 9)$ or $50-59 \%(55 \%$; 9) of body length from anterior body end, post-caecal distance 152-243 $(188 ; 9)$ or $41-49 \%(45 \% ; 9)$ of body length from posterior body end (Figs. 11, 14).

Testicular anlage $49-101(69 ; 10)$ long or $12-20 \%$ $(16 \% ; 10)$ of body length, $51-110(85 ; 10)$ wide or $49-73 \%$ $(63 \% ; 10)$ of body width or $0.6-1.0 \times(0.8 \times ; 10)$ longer than wide, containing dense field of vasa efferentia intertwining among densely-packed testicular cells; testicular cells circular, each measuring 1 in diameter; post-testicular space $110-163(133 ; 10)$ long or $27-36 \%(31 \% ; 10)$ of body length (Fig. 11). Vasa efferentia secondary ducts $11-35(21 ; 10)$ in maximum width (Fig. 11). Vas deferens a thin-walled duct, including a proximal portion ventral to testicular anlage and a post-testicular portion; proximal portion robust, comprising 1 trunk, $11-35(21 ; 10)$ in max- imum width, extending from lateral margins of testicular lobes, typically orienting diagonally posterosinistral (6 of 10 specimens), and occasionally orienting diagonally posterodextral ( 2 of 10 specimens) or along midline ( 2 of 10 specimens); post-testicular field portion 66-157 (110; 10) long, $6-22(13 ; 10)$ wide at the level of posterior margin of testicular anlage, typically extending diagonally sinistrad $12-38(26 ; 9)$ or $3-9 \%(5 \% ; 9)$ of body length before curving toward dextral body margin dorsally ( 9 specimens vs 1 ventrally) and extending $15-45(33 ; 10), 5-15(11 ; 9)$ wide at level of ovary, curving ventromedially ( 9 specimens $v s$ 1 dorsally) and crossing midline for 32-80 (54; 10), 9-17 $(14 ; 10)$ wide or $9-13 \%(11 \% ; 10)$ of maximum body width before connect with cirrus-sac and internal seminal vesicle, ventral to ovary (Figs. 11, 15, 16).

Cirrus-sac oblong, 45-65 $(53 ; 10)$ long or $9-14 \%(13 \%$; $10), 11-19(16 ; 10)$ in maximum width or $11-14 \%(12 \%$; $10)$ of body width, having wall approximately $1(1 ; 10)$ thick, thin-walled; internal seminal vesicle robust, 32-65 (52;10) long, 5-11 $(7 ; 10)$ wide or $5.6-9.8 \times(7.6 \times ; 10)$ longer that wide, curving posteriad and orienting diagonally posteromedial (Figs. 11, 15, 16). Male genital pore circular, 2-3 $(3 ; 10)$ wide, slightly sinistral, opening $24-41$ $(34 ; 10)$ or $20-29 \%(25 \% ; 10)$ of maximum body width from sinistral body margin, opening $35-51(45 ; 10)$ or $27-41 \%(33 \% ; 10)$ of maximum body width from dextral body margin, $48-80(62 ; 10)$ or $13-18 \%(14 \% ; 10)$ of body length from posterior body end (Figs. 11, 15, 16). 
Ovarian anlage hard to delineate in most of specimens fixed, having approximately $3(3 ; 1)$ dextral and $2(2 ; 1)$ sinistral branches each $3(3 ; 5)$ wide, branches difficult to delineate in most specimens; post-ovarian space 100-103 $(102 ; 2)$ long or $25-26 \%(25 \% ; 2)$ of body length (Figs. 11 , $15,16)$. Oviduct curving sinistrally immediately posterior to ovary and lateral to vas deferens, $105-158(126 ; 6)$ long or $25-32 \%(29 \% ; 6)$, including an abbreviated proximal duct, a dilated portion (= oviducal seminal receptacle), and a narrow distal portion; proximal duct emanating from posteroventral surface of ovary extending sinistrally 10-20 $(13 ; 6), 2-3(2 ; 6)$ in maximum width, curving posteromediad to connect with oviducal seminal receptacle; oviducal seminal receptacle $40-80(59 ; 6)$ long or $37-52 \%(47 \% ; 5)$ of total oviduct length, $5-16(9 ; 6)$ wide or $5-11 \times(8 \times ; 6)$ longer than wide, occupying space between vas deferens and sinistral body margin, crossing vas deferens dorsally, post-ovarian; distal portion of oviduct $2-3(2 ; 10)$ or $13-60 \%(35 \%, 6)$ of oviducal seminal receptacle width, continuing posteriad approximately in parallel with dextral body margin before uniting with vitelline duct (Figs. 11, $15,16)$. Ootype 10-18 (16; 10) long, 7-11 (9; 10) wide, $1.4-2.1 \times(1.7 \times ; 10)$ longer than wide, slightly dextral to midline, orienting parallel to long axis of body; postootype distance $35-65(50 ; 10)$ or $10-14 \%(12 \% ; 10)$ of body length from posterior body end (Figs. 11, 15, 16). Uterine anlage occupying space between cirrus-sac and distal portion of oviduct; 16-30 (24; 9) long or 4-8\% (6\%; 9 ) of body length, first portion of ascending uterus difficult to trace in most specimens (7 of 10 specimens), approximately $5-9(7 ; 7)$, becoming refractive and curving sinistrad 13-22 $(18 ; 7)$ before connecting metraterm; metraterm dilating 5-8 $(7 ; 9)$ and extending $6-11(8 ; 9)$, narrowing to $2(2 ; 9)$ and extending about 4-6 (5; 9) (Figs. 11, 15, 16). Female genital pore not observed.

Excretory system not observed.

H o s t: Pimelodus grosskopfii (Steindachner) (Siluriformes: Pimelodidae).

L o c a lit y: Cienega de Jobo and Canal del Dique (10²0'59"N; $\left.74^{\circ} 58^{\prime} 00^{\prime \prime} \mathrm{W}\right)$, Magdalena River Drainage, Colombia.

Site in host: Body cavity.

Prevalence and intensity of infection: Three of 9 (33\%) P. grosskopfii collected at Cienega de Jobo and Canal del Dique, Colombia had 7-26 specimens (mean intensity = $14 \pm 0.5)$.

Specimens deposited: Two vouchers at the United States National Museum (USNM Coll. No. 1283482 and 1283483); one voucher at the Institute of Parasitology, Academy of Sciences of the Czech Republic, České Budějovice (IPCAS D-718).

Remarks. We identified these specimens as Plehniella sp. based on the presence of the following characteristics: body ovoid, lateral tegumental spines lacking; pharynx lumen triradiate, minute; anterior and posterior oesophageal swellings robust, thick-walled; intestine comprising 6 caeca; testis lobed; cirrus-sac present; ootype prominent; uterus short; metraterm present. The specimens of Plehniella sp. differ from their congeners by the combination of hav- ing a posteriorly-constricted body region, an anterior sucker with concentric rows of minute spines, an elongate anterior oesophageal swelling (1/6 oesophagus length), short and wide caeca ( $1 / 10$ body length; $>1 / 2$ body width), and a male genital pore that opens proportionally more anteriad (1/7 body length from posterior body end). As described above, $P$. coelomicola and $P$. sabajperezi differ from the specimens of Plehniella sp. by having a relatively elongate body and relatively short caeca (terminating in anterior body half). Our specimens of $P$. armbrusteri can be differentiated most easily from those of Plehniella sp. by having a relatively oblong-ovoid body and long caeca (nearly $1 / 2$ body length). None of the aforementioned nominal species has a posterior body constriction, an anterior sucker, or spines associated with the body; however, all have a male genital pore that opens near the posterior body extremity.

We speculate that the specimens of Plehniella sp. were small adult specimens based on the proportionally large size of the genitalia (nearly $1 / 2$ body length). Because of this, we posit that some of the differences between these putatively younger specimens and our other specimens (those of P. sabajperezi and P. armbrusteri) are likely associated with fluke development, e.g. presence/absence of anterior sucker and associated spination, location of genital pore. However, noteworthy is that other workers have used body size to differentiate congeneric adult fish blood flukes (e.g. Nolan and Cribb 2006a,b, Bullard et al. 2012). Hence, we included a detailed description of these specimens herein so that a future worker(s) could explore this host for infections, perhaps revealing the presence of another new species of Plehniella.

It is noteworthy that the small, putatively young, adult specimens of Plehniella sp. have a spheroid anterior sucker with concentric spine rows, whereas the large specimens of the new species lack a demarcated anterior sucker or associated spines. Although the specimens of Plehniella sp. were collected from body cavity, we speculate that perhaps they had recently arrived in that site and that the sucker and spines are lost during subsequent development. Whether or not any species of Plehniella keeps a spinous anterior sucker throughout life, or whether younger specimens of the new species have a spinous anterior sucker, is indeterminate.

\section{DISCUSSION}

A major portion of the results presented herein are based on specimens collected from formalin-fixed fishes (collected between 1978 and 2007) that reside within the Auburn University Museum of Natural History. From a parasitological perspective, fish collections offer a great opportunity to sample a wide geographic, ecological and phylogenetic diversity of fishes without having to expend resources to support a field expedition. This approach seems particularly promising in filling geographic and taxonomic gaps for aporocotylids that infect the body cavity. As evidenced by the present study, taxonomically useful, although not ideal, specimens can be readily obtained from museum-curated fish specimens without causing significant damage to the fish specimen (our parasite materials 
were obtained by making a slit in abdomen and rinsing the body cavity). Moreover, assessments of museum fish specimens for parasite infections could represent a critical component in 'before-after' baseline comparisons, once those collections offer a unique opportunity to obtain samples from time points before a man-made disturbance takes place. Currently, those comparisons are available for studies of human parasites, where those data are recorded during a disease outbreak but little information is known for comparisons in fish parasite populations. For example, the construction of dams have been implicated as the major factor leading to increased prevalence and transmission of schistosomiasis, a disease caused by blood flukes that are close relatives of aporocotylids (Gryseels et al. 1994, N'Goran et al. 1997, Orélis-Ribeiro et al. 2014).

Herein, we report a concurrent infection of aporocotylids (i.e. P. sabajperezi and P. armbrusteri) in a South American pimelodid (i.e. Bloch's catfish, P. blochii). Few hosts have been reportedly concurrently infected by congeneric fish blood flukes: Cardicola forsteri Cribb, Daintith et Munday, 2000 and Cardicola orientalis Ogawa, Tanaka, Sugihara et Takami, 2010 from southern bluefin tuna, Thunnus maccoyii Castelnau (see Shirakashi et al. 2013); Cardicola orientalis and Cardicola opisthorchis Ogawa, Ishimaru, Shirakashi, Takami et Grabner, 2011 from pacific bluefin tuna, Thunnus orientalis (Temminck et Schlegel) (see Ogawa et al. 2011, Shirakashi et al. 2012); Paradeontacylix grandispinus Ogawa et Egusa, 1986 and Paradeontacylix kampachi Ogawa et Egusa, 1986 from greater amberjack, Seriola dumerili Risso, 1810 (Ogawa and Egusa 1986, Repullés-Albelda et al. 2008). We mention this here simply because it may be ecologically significant regarding host-parasite immunocompatibility and, clearly, few examples of concurrent infections by blood-dwelling flatworms exist in the primary literature.

Several morphology-based studies have supported the view that phylogenetically related definitive hosts are infected by morphologically similar (congeneric) fish blood flukes (Bullard and Overstreet 2004, 2006, Bullard et al. 2008, Orélis-Ribeiro et al. 2013, Bullard 2014). Within a host family or genus, that phenomenon is harder to discern. For example, Pimelodus (Lacepède) is a paraphyletic assemblage that requires revision (Lundberg and Littmann 2003, Lundberg et al. 2011). Yet, the available evidence from morphological and molecular data on the interrela- tionships of South American pimelodids suggest that related species of Pimelodus have morphologically similar species of Plehniella. For example, according to Lundberg et al. (1991) and Lundberg and Parisi (2002), the presence of a trigeminofacial nerve complex is shared by four catfishes that are infected by Plehniella spp., i.e. P. maculatus (type species), P. blochii, P. grosskopfii, and Iheringichthys labrosus. Noteworthy also is that the topology of the latest molecular phylogeny on South American pimelodids indicated a P. blochii species complex (Lundberg et al. 2011). As such, we believe that the concurrent infection of $P$. armbrusteri and P. sabajperezi in P. blochii may prove to be a further evidence of this cryptic speciation.

Approximately 17\% (19 of 109) of the accepted species of Pimelodidae have been described since 2005 (Eschmeyer and Fong 2015) and likely many species remain unnamed (Armbruster 2011). As such, it seems plausible to also predict an increasing number of overlooked infections of Plehniella spp. Beyond the cryptic diversity, it seems clear that much remains to be documented regarding the definitive host range, geographic distribution, general biology, and taxonomy of blood flukes that infect pimelodid species. Adding complexity to this scenario, no intermediate host is known for any species of South American aporocotylid, although no shortage of candidates exists. Alda and Martorelli (2014) recently described a cercaria that infects gonad and digestive gland of the intertidal mud snail Heleobia australis (d'Orbigny) (Rissooidea: Cochliopidae) in Argentina. It had most of the key morphological features of aporocotylid cercariae: minute body with an anterior sucker armed with concentric spines, forked tail with fin fold present on the tail furcae, and no ventral sucker (Orélis-Ribeiro et al. 2014).

Acknowledgements. We thank Jonathan W. Armbruster and David C. Werneke (Auburn University Museum of Natural History) for assistance obtaining the catfish voucher specimens herein studied; Stephen S. Curran (GCRL, University of Southern Mississippi) for providing the aporocotylid specimen from Bloch's catfish collected in the Napo River, Peru; and Anna Phillips, Katie Ahlfeld and William Moser (Department of Invertebrate Zoology at the National Museum of Natural History) for ensuring the safe deposition of our type materials. This study was supported in part by the National Science Foundation's Division of Environmental Biology with funds from NSF-DEB grant numbers 1112729 , 1051106 and 1048523.

\section{REFERENCES}

Alda P., Martorelli S.R. 2014: Larval trematodes infecting the South American intertidal mud snail Heleobia australis (Rissooidea: Cochliopidae). Acta Parasitol. 59: 50-67.

Armbruster J.W. 2011: Global Catfish Biodiversity. Am. Fish. Soc. Symp. 77: 15-37.

Avendaño de Mac Intosh F., Ostrowski de Núñez M. 1998 Seasonal dynamics of Plehniella coelomica (Trematoda: Aporocotylidae) in two catfish, Pimelodus albicans and P. maculatus (Pisces: Siluriformes), from La Plata River, Argentina. Folia Parasitol. 45: 253-255.

Brasil-Sato M.C. 2003: Parasitos de peixes da bacia do São Francisco. In: H.P. Godinho and A.L. Godinho (Eds.), Águas, Peixes e Pescadores do São Francisco das Minas Gerais. PUC Minas, Belo Horizonte, pp. 149-165.

Brasil-Sato M.C., Pavanelli G.C. 2004: Digenea de Pimelodus maculatus (Osteichthyes: Pimelodidae) das bacias dos rios São Francisco e Paraná, Brasil. Parasitol. Lat. Am. 59: 123-131.

Brown C.E. 1956: Composition of Scientific Words: A Manual of Methods and a Lexicon of Materials for the Practice of Logotechnics. Smithsonian Institution Press, Washington, D.C., 881 pp.

Bullard S.A. 2014: Blood flukes (Digenea: Aporocotylidae) of Elopomorpha: emended diagnosis of Paracardicoloides, supplemental observations of Paracardicoloides yamagutii, and a new 
genus and species from ladyfish, Elops saurus in the northern Gulf of Mexico. J. Parasitol. 100: 305-316.

Bullard S.A., Baker T., DE Buron I. 2012: New species of Cardicola Short, 1953 (Digenea: Aporocotylidae) from heart of Atlantic croaker, Micropogonias undulatus (Sciaenidae), of the South Atlantic Bight. J. Parasitol. 98: 328-332.

Bullard S.A., Jensen K., Overstreet R.M. 2009: Historical account of the two family-group names in use for the single accepted family comprising the "fish blood flukes." Acta Parasitol. 54: 78-84.

Bullard S.A., Overstreet R.M. 2004: Two new species of Cardicola Short, 1952 (Digenea: Sanguinicolidae) from the heart of drums (Sciaenidae) in the northern Gulf of Mexico. J. Parasitol. 90: 128-136.

Bullard S.A., Overstreet R.M. 2006: Psettarium anthicum sp. n. (Digenea: Sanguinicolidae) from the heart of cobia Rachycentron canadum (Rachycentridae) in the northern Gulf of Mexico. Folia Parasitol. 53: 117-24.

Bullard S.A., Snyder S.D., Jensen K., Overstreet R.M. 2008: New genus and species of Aporocotylidae (Digenea) from a basal actinopterygian, the American paddlefish, Polyodon spathula (Acipenseriformes: Polyodontidae), from the Mississippi Delta. J. Parasitol. 94: 487-95.

EJSMONT L. 1926: Morphologische, systematische und entwicklungsgeschichtliche Untersuchungen an Arten des genus Sanguinicola Plehn. Bull. Int. Acad. Polonaise Sci. Lettres, serie B, 9-10B: 877-966.

EsChMEYeR W.N. 2015: Catalog of fishes. http://www.calacademy. org/scientists/projects/catalog-of-fishes, 02/2015.

Eschmeyer W.N., Fong J.D. 2015: Species of fishes by family/ subfamily. http://researcharchive.calacademy.org/research/ichthyology/catalog/SpeciesByFamily.asp, 02/2015.

Froese R., Pauly D. (Eds.) 2015: FishBase. World Wide Web electronic publication, www.fishbase.org, 02/2015

Gryseels B., Stelma F.F., Talla I., van Dam G.J., Polman K., Sow S., Diaw M., Sturrock R.F., Decam C., Niang M., Doenring-Schwerdtfeger E., Kardorff R. 1994: Epidemiology, immunology and chemotherapy of Schistosoma mansoni infections in a recently exposed community in Senegal. Trop. Geogr. Med. 46: 209-219.

Guidelli G.M., IsaAc A., Pavanelli G.C. 2002: Sanguinicola platyrhynchi sp. n. (Digenea: Sanguinicolidae) parasite of visceral cavity of Hemisorubim platyrhynchos (Valenciennes, 1840) (Pisces: Pimelodidae) from the floodplain of the upper Paraná River, Brazil. Braz. J. Biol. 64: 801-806. (In Portuguese with English summary.)

Imam E.A., El-AsKalany M.A. 1990: An approach to helminth parasites of catfish (Clarias lazera) in Beni-Suef Governorate. Assiut Vet. Med. J. 24: 96-107.

Imam E.A., Marzouk M.S.M., Hassan A.A., Itman R.H. 1984: Studies on Sanguinicola sp. (Trematoda) of Nile fishes. Vet. Med. J. Egypt 32: 1-13.

KHALIL L.F. 1969: Studies on the helminth parasites of freshwater fishes of the Sudan. J. Zool. London 158: 143-170.

Khalil L.F. 1971: Checklist of the Helminth Parasites of African Freshwater Fishes. Tech. Comm. 42, Comm. Inst. Helm., C.A.B. England, $80 \mathrm{pp}$.

LuNASCHI L.I. 1985: Helmintos parasitos de peces de agua dulce de la Argentina IV. Acerca de la validez del género Plehniella Szidat, 1951 (Trematoda - Sanguinicolidae). Neotropica 31: $149-154$.

Lundberg J.G., Littmann M.W. 2003: Family Pimelodidae (long-whiskered catfishes). In: R.E. Reis, S.O. Kullander and C.J. Ferraris Jr. (Eds.), Check List of the Freshwater Fishes of South and Central America. Edipucrs, Porto Alegre, pp. 432-446.

Lundberg J.G., Mago-Leccia F., Nass P. 1991: Exalloduntus aguanai, a new genus and species of Pimelodidade (Pisces: Siluriformes) from deep river channels of South America, and delimitation of the subfamily Pimelodinae. Proc. Biol. Soc. Wash. 104: 840-869.
Lundberg J.G., Parisi B.M. 2002: Propimelodus new genus, and redescription of Pimelodus eigenmanni Van der Stigchel 1946, a long-recognized yet poorly-known South American catfish (Pimelodidae: Siluriformes). Proc. Acad. Nat. Sci. Philad. 152: $75-88$.

Lundberg J.G., Sabaj Pérez M.H., Dahdul W.M., Aguilera O.A. 2010: The Amazonian Neogene fish fauna. In: C. Hoorn and F.P. Wesselingh (Eds.), Amazonia - Landscape and Species Evolution: a Look into the Past. Wiley-Blackwell, Chichester, pp. 281-301.

Lundberg J.G., Sullivan J.P., Hardman M. 2011: Phylogenetics of the South American catfish family Pimelodidae (Teleostei: Siluriformes) using nuclear and mitochondrial gene sequences. Proc. Acad. Nat. Sci. Philad. 161: 153-189.

Nelson J.S. 2006: Fishes of the World, Fourth Edition. John Wiley and Sons, New York, $601 \mathrm{pp}$.

N'Goran E.K., Diabate S., Utzinger J., Sellin B. 1997: Changes in human schistosomiasis levels after the construction of two large hydroelectric dams in central Côte d'Ivoire. Bull. WHO 75: 541-545.

Nolan M.J., CribB T.H. 2005: Sanguinicola maritimus n. sp. (Digenea: Sanguinicolidae) from Labridae (Teleostei: Perciformes) of southern Australian waters. Syst. Parasitol. 61: 99-106.

Nolan M.J., CribB T.H. 2006a: An exceptionally rich complex of Sanguinicolidae von Graff, 1907 (Platyhelminthes: Trematoda) from Siganidae, Labridae and Mullidae (Teleostei: Perciformes) from the Indo-west Pacific Region. Zootaxa 1218: 1-80.

Nolan M.J., CribB T.H. 2006b: Cardicola Short, 1953 and Braya n. gen. (Digenea: Sanguinicolidae) from five families of tropical Indo-Pacific fishes. Zootaxa 1265: 1-80.

Odhner T. 1924: Remarks on Sanguinicola. Quart. J. Microsc. Sci. 68: 403-411.

Ogawa K., Egusa S. 1986: Two new species of Paradeontacylix McIntosh, 1934 (Trematoda: Sanguinicolidae) from the vascular system of a cultured marine fish Seriola purpurascens. Fish Pathol. 21: 15-19.

Ogawa K., Ishimaru K., Shirakashi S., Takami I., Grabner D. 2011: Cardicola opisthorchis n. sp. (Trematoda: Aporocotylidae) from the Pacific bluefin tuna, Thunnus orientalis (Temminck \& Schlegel, 1844), cultured in Japan. Parasitol. Int. 60: 307-312.

Orélis-Ribeiro R., Arias C.R., Halanych K., Cribb T.H., Bullard S.A. 2014: Diversity and ancestry of flatworms infecting the blood of non-tetrapod chordates. Adv. Parasitol. 85: $1-64$.

Orélis-Ribeiro R., Ruiz C.F., Curran S.S., Bullard S.A. 2013: Blood flukes (Digenea: Aporocotylidae) of lamniforms: Redescription of Hyperandrotrema cetorhini from basking shark (Cetorhinus maximus) and description of a new congener from shortfin mako shark (Isurus oxyrinchus) off Alabama. J. Parasitol. 99: 835-846.

PAPERnA I. 1964: Parasitic helminths of inland-water fishes in Israel. Israel J. Zool. 13: 1-20.

Paperna I. 1996: Parasites, Infections and Diseases of Fishes in Africa. An update. Committee for Inland Fisheries of Africa (CIFA) Tech. Paper No. 31, FAO, Rome, 220 pp.

Plehn M. 1905: Sanguinicola armata und inermis (n. gen., sp. n.) n. fam. Rhynchostomida. Ein entoparasitisches Turbellar im Blut von Cypriniden. Zool. Anz. 29: 224-252.

Reis R.E. 2013: Conserving the freshwater fishes of South America. Int. Zoo. Yearb. 47: 65-70.

Repullés-Albelda A., Montero F.E., Holzer A.S., Ogawa K., Hutson K.S., Raga J.A. 2008: Speciation of the Paradeontacylix spp. (Sanguinicolidae) of Seriola dumerili. Two new species of the genus Paradeontacylix from the Mediterranean. Parasitol. Int. 57: 405-14.

Shirakashi S., Kishimoto Y., Kinami R., Katano H., Ishimaru K., Murata O., Itoh N., Ogawa K. 2012: Morphology and distribution of blood fluke eggs and associated pathology 
in the gills of cultured Pacific bluefin tuna, Thunnus orientalis. Parasitol. Int. 61: 242-249.

Shirakashi S., Tsunemoto K., Webber C., Rough K., Ellis D., Ogawa K. 2013: Two species of Cardicola (Trematoda: Aporocotylidae) found in southern bluefin tuna Thunnus maccoyii ranched in South Australia. Fish Pathol. 48: 1-4.

Sмiтh J.W. 2002: Family Sanguinicolidae von Graff, 1907. In: D.I. Gibson, A. Jones and R. Bray (Eds.), Keys to the Trematoda. CABI Publishing, Wallingford, pp. 433-452.

Szidat L. 1951: Neue Arten der trematodenfamilie Aporocotylidae aus dem Blut und der Leibeshohle von Süsswasserfischen des Rio de la Plata. Z. Parasitenkd. 15: 70-86.
Takemoto R.M., Pavanelli G.C., Lizama M.A.P., Lacerda A.C.F., Yamada F.H., Moreira L.H.A., Ceschini T.L., BelLAY S. 2009: Diversity of parasites of fish from the Upper Paraná River floodplain, Brazil. Braz. J. Biol. 69: 691-705.

Truong T.N., Bullard S.A. 2013: Blood flukes (Digenea: Aporocotylidae) of walking catfishes (Siluriformes: Clariidae): new genus and species from the Mekong River (Vietnam) and a note on catfish aporocotylids. Folia Parasitol. 60: 237-247.

Woodland W.N.F. 1923: Sanguinicola from the Sudan. Quart. J. Microsc. Sci., New Series 67: 233-242.

Yamaguti S. 1958: Systema Helminthum. Vol. 1. The Digenetic Trematodes of Vertebrates. Interscience, New York, 1575 pp.

Cite this article as: Orélis-Ribeiro R., Bullard S.A. 2015: Blood flukes (Digenea: Aporocotylidae) infecting body cavity of South American catfishes (Siluriformes: Pimelodidae): two new species from rivers in Bolivia, Guyana and Peru with a re-assessment of Plehniella Szidat, 1951. Folia Parasitol. 62: 050 